\title{
A sedimentação em uma abordagem sistêmica
}

\author{
Sedimentation In a SYSTEMIC APPROACH.
}

Henrique Zerfass ${ }^{1}$, Geise de Santana dos Anjos Zerfass ${ }^{2}$

1 - Petróleo Brasileiro S/A, Universidade Petrobras, Escola de Ciência e Tecnologia de E\&P. Rua Ulisses Guimarães 565, $8^{0}$ andar -20211-

225, Rio de Janeiro, RJ, henrique.zerfass@petrobras.com.br

2 - Petróleo Brasileiro S/A, CENPES /PDGE0/Gerência de Bioestratigrafia e Paleoecologia Aplicada. Avenida Horácio Macedo, 950, Ilha do

Fundão, 21941-915 Rio de Janeiro, RJ, Brasil.geise.zerfass@petrobras.com.br.

ABSTRACT: Sedimentation can be considered as a system on the surface of the Earth. It exhibits a fundamental attribute of a system, the equifinality, which is expressed by the search for stability between erosion and deposition. A sedimentary system exhibits mass and energy inputs and outputs, and internal mass transfer. Energy is added in the form of thermal and gravitational energy. Mass entry occurs by absorption of atmospheric gases, rain and snow, weathering and erosion, and photosynthesis. Energy leaves the system by heat loss and chemical energy accumulation in rocks. Mass is lost by incorporation into the stratigraphic record, organic matter degradation and gas release to the atmosphere. A division into sub-systems is also possible, based on the driving energy: (i) inertia, (ii) density gradients, (iii) tides and (iv) waves. From the didactic point of view, the systemic view brings issues like sedimentology, paleontology and geochemistry closer together.

\author{
Manuscrito: \\ Recebido: \\ Corrigido: \\ Aceito: \\ Citation: Zerfass H., Anjos-Zerfass \\ G.S.. 2016. A sedimentação em \\ uma abordagem sistêmica. Ter- \\ ræ Didatica, 12(2):126-149. \\ <http://www.ige.unicamp.br/ \\ terraedidatica/ $>$.
}

Keywords: General System Theory, sedimentation..

\section{Introdução}

O estudo das rochas sedimentares está fundamentado nos princípios atualistas, em que os processos de sedimentação são o ponto de partida para a interpretação das fácies e associações de fácies no registro sedimentar. Nos currículos dos cursos de geologia, a disciplina de sedimentologia aborda os métodos de interpretação paleoambiental, sob o ponto de vista dos processos físicos, com um embasamento teórico oriundo da hidráulica. No entanto, em geral, os processos químicos e biológicos são relegados a um segundo plano.

A disciplina de paleontologia, por sua vez, volta o seu olhar para o fóssil, como organismo ou como clasto sedimentar. As interações dos organismos com o seu ambiente, as quais influenciam os processos de sedimentação, muitas vezes não são abordadas, especialmente se não deixarem no registro restos fossilizados. Apenas a paleoicnologia faz esta abordagem, mas como se trata de uma disciplina mais específica, nem sempre está presente nos currículos de graduação.
Nos mesmos currículos, a geoquímica exógena abrange os processos químicos ambientes superficiais, inorgânicos e biogênicos. Entretanto, essa disciplina tem uma área de atuação mais ampla, que envolve também os processos diagenéticos e de formação de depósitos minerais em rochas sedimentares, restando pouco espaço para o desenvolvimento de conteúdos voltados à sedimentação (que frequentemente não são abordados).

Existe, portanto, uma lacuna no estudo da sedimentação, no que diz respeito à interação entre os processos biológicos e químicos e os de origem física, que configura o quadro final do ambiente de sedimentação, o qual é mais amplo do que o modelo de fácies sedimentológico.

A moderna sedimentologia tem como foco principal os processos físicos. Esta abordagem começou a ser utilizada a partir dos anos 1960, e importantes trabalhos didáticos pioneiros foram realizados, entre eles os de Allen (1966, 1968, 1970) e Reineck \& Singh (1980). A posição de destaque dos processos de sedimentação é ine- 
gável no programa de pesquisa contemporâneo. No entanto, considera-se que a organização dos modelos de fácies em ambientes de sedimentação, especialmente os siliciclásticos, segue uma lógica fisiográfica, como atestam alguns dos mais importantes trabalhos didáticos no assunto (e.g. Walker 1992, Reading 1996, James \& Dalrymple, 2010). Vale ressaltar que embora não seja absolutamente errônea, esta abordagem causa a segmentação do conhecimento.

Todo o processo de sedimentação pode ser considerado como um sistema aberto de acordo com a Teoria Geral dos Sistemas, desenvolvida a partir dos trabalhos de Ludwig von Bertalanffy (cf. Bertalanffy 1968). O autor aponta vários exemplos da aplicação desta teoria ao mundo físico, embora nenhum em Geologia. Não obstante, o sistema sedimentar apresenta todos os elementos que caracterizam um sistema aberto, como entrada e saída de massa e de energia e existência de interações entre os constituintes, estes representados pelas partículas sedimentares, fluidos, íons e componentes bióticos.

De acordo com a proposta original da teoria, um sistema pode ser organizado em subsistemas. Aqui se propõe que um subsistema seja um domínio de processos cuja energia ativadora tenha uma origem distinta. A energia pode ter origem (i) diretamente pela ação da gravidade terrestre (inercial), (ii) em gradientes de densidade, (iii) nas ondas e (iv) nas marés.

Neste artigo é apresentada uma abordagem alternativa do sistema sedimentar, como uma proposta didática aos cursos de geociências, onde o caráter holístico possibilita que os docentes trabalhem com mais facilidade a questão das interações entre uma quantidade grande de elementos.

\section{A Teoria Geral dos Sistemas}

\section{Aspectos gerais}

Segundo Branco (1989), o termo "sistema", cujo sentido literal é de "construção solidária" (do grego "syn" - "junto" e "thesis" - "associado"), já havia sido utilizado na ciência e na filosofia modernas de diferentes formas, mas tendo em comum a ideia de conjunto e organização interna. No século XVII, Lineu publicou o famoso Systema Naturae, no qual se propunha a fazer uma organização criteriosa da natureza e, no século XVIII, Condillac escreveu o Tratado dos Sistemas, em que discutiu essencialmente sistemas de pensamento que possuíam sua identidade centrada em "princípios" que estabeleciam a relação entre os seus componentes (Branco 1989).

Um grande passo para a construção de uma visão sistêmica da natureza foi dado com o desenvolvimento da termodinâmica no final do século XIX. A termodinâmica tornou possível aos físicos tratar realidades complexas, com um número muito grande de elementos; por isso, uma nova abordagem matemática passou a ser utilizada, fundamentada na estatística (Huggett 2007). A física das partículas subatômicas também abriu novas possibilidades, uma vez que partículas de massas ínfimas e instáveis que vêm sendo descobertas têm pouco significado quando isoladas, mas possuem um importante papel no funcionamento do átomo (Humbert 1972). A ciência reducionista chegava ao limite de suas possibilidades: a matéria havia sido tão dissociada que não mais fazia sentido analisar as suas partes separadamente, tendo-se tornado necessário o retorno aos sistemas físicos.

Ludwig von Bertalanffy publicou, entre as décadas de 1920 e 1960, uma série de trabalhos os quais estão sumarizados em Bertalanffy (1968). Nesses trabalhos o autor lançou as bases da Teoria Geral dos Sistemas, como um "novo paradigma científico (em contraste com o paradigma analítico, mecanicista, causal, numa só direção da ciência clássica)". Humbert (1972) comparou a construção mecanicista da natureza a um quebra-cabeça que, quando montado, permanece estático. Os sistemas, ao contrário, possuem seus elementos associados de forma dinâmica.

A Teoria Geral dos Sistemas define um sistema como um "conjunto de elementos em interação" (Bertalanffy 1968), com uma finalidade objetiva que é atingir sua estabilidade. A estabilidade seria atingida com o contrabalanço entre a entrada e a saída de massa e energia, já que se trata de sistemas abertos. Nesse estado, o sistema se mantém constante, mas matéria e energia seguem fluindo através dele (Huggett 2007). Em contrapartida, os sistemas fechados da Teoria Termodinâmica tendem ao estado de entropia máxima ou "equilíbrio", que ao mesmo tempo é a morte do sistema.

Ao contrário dos sistemas termodinâmicos teóricos, os sistemas identificáveis na realidade passam por fases em que sua entropia diminui. Isto se deve à contínua entrada de massa, que pode ocorrer na forma de elementos mais organizados do que aqueles que já estão inseridos no sistema. 
Isto explica porque o desenvolvimento de um organismo ou a evolução de um grupo orgânico tende a uma maior complexidade e organização, contrariando a segunda lei da termodinâmica. Isto pode ser expresso pela equação de Prigogine (apud Bertalanffy 1968),

$$
d S=d_{e} S+d S,
$$

onde $\mathrm{d}_{\mathrm{i}} \mathrm{S}$ é a produção de entropia positiva do sistema, por meio de processos irreversíveis, e $\mathrm{d}_{\mathrm{e}} \mathrm{S}$ é a variação de entropia por importação, esta última podendo ser positiva ou negativa. A variação nula de entropia caracteriza o estado estacionário que um sistema aberto pode atingir (Humbert 1972). A importação de entropia negativa torna possível uma crescente organização do sistema aberto. $\mathrm{Na}$ linguagem da Teoria da Informação, um sistema menos organizado pode receber informação; onde esta palavra tem o sentido de dar forma ou organizar (Branco 1989).

Bertalanffy (1968) também chamou a atenção para a capacidade que os sistemas abertos têm de realizar trabalho, ao contrário dos sistemas fechados que, para realizar trabalho, necessitam importar energia. $\mathrm{O}$ autor também enfatizou que um sistema aberto importa e exporta matéria, e que internamente seus componentes são construídos e destruídos constantemente. Esta questão é muito importante em se tratando da sedimentação.

As interações entre os elementos (ou indivíduos) são ao menos tão importantes quanto os próprios, o que faz com que um sistema não possa ser segmentado sem perder a sua identidade. Esta é a diferença entre a visão sistêmica e a visão mecanicista da ciência. Esta última considera que um todo é organizado em partes, como peças de uma máquina e, uma vez conhecidas as peças, é possível reconstruir-se a máquina. Bertalanffy (1968) considera que a ciência contemporânea se deparou com "problemas de organização", que não se resolvem nem por meio do entendimento dos fenômenos separadamente nem pelo isolamento de partes.

Outro aspecto muito importante apontado por Bertalanffy (1968) é o "princípio da equifinalidade", segundo o qual as condições finais serão as mesmas, ainda que variem as condições iniciais. Em outras palavras, pode haver variações no momento da entrada de massa e energia, mas o sistema sempre "trabalha" no intuito de atingir a sua finalidade. Ao se referir ao ecossistema, Branco (1989) afirmou que sua finalidade é conduzir a energia com o máximo de eficiência, o que pode ser também aplicado a outros tipos de sistemas. Branco (1989) ainda destacou que este sentido de finalidade - uma "tendência probabilística" - não deve ser confundido com aquele da doutrina finalista de que todas as coisas se realizam conforme um plano pré-estabelecido, em todos os seus detalhes.

Um sistema pode ainda ser organizado em subsistemas. Embora este aspecto não esteja definido formalmente em Bertalanffy (1968), a Teoria Geral do Sistema admite que um sistema complexo possa conter áreas em que seus elementos estejam mais intimamente relacionados. Essas áreas por sua vez trocam matéria e energia com outros setores do sistema. Ao se abordar a superfície da Terra ou qualquer outro sistema em que a extensão espacial seja relevante, os subsistemas passam a ser muito importantes.

Segundo Bertalanffy (1968), a Teoria Geral do Sistema rompeu com as relações lineares de causa e consequência, propondo problemas e soluções com multivariáveis. Isto requer uma abordagem transdisciplinar para os problemas da ciência. A visão transdisciplinar permite discernir um "todo significativo", que emerge do diálogo entre as partes e o todo (Mello et al. 2002). Para a presente argumentação, também se considera aqui o conceito de transdisciplinaridade dado por B. Nicolescu, de "aprender a conhecer", de se estabelecer pontes entre os diversos saberes para que o conhecimento faça sentido na vida cotidiana (Silva 2007).

\section{Exemplos de aplicação em Geociências}

Nas geociências, o conceito de sistema tem sido aplicado especialmente em geomorfologia. G. K. Gilbert, no final do século XIX, considerava que a paisagem buscava o "equilíbrio dinâmico" (Huggett 2007). Em sua obra sobre a geologia e a evolução da paisagem das Montanhas Henry (Utah, EUA), Gilbert (1877), enfatizou a busca que as drenagens fazem de uma situação de estabilidade, o rio gradado, que seria a forma mais eficiente de transporte de água e sedimento. Nesta situação, haveria uma interdependência de todas as partes e elementos da drenagem. O geomorfólogo W. M. Davis endossou as relações observadas por Gilbert, afirmando que o rio gradado é aquele que atinge o máximo de organização e de interdependência entre todas as suas partes (Davis 1902).

No final do século XIX, J. Walther considerava os processos da superfície da Terra como a interação entre o mundo orgânico e o inorgânico. É notável 
a observação de Walther (1894) de que o mesmo resultado, em termos de fácies sedimentares, poderia ser atingido por diferentes processos. Também foi um passo importante a visão de Walther de que, nos processos de sedimentação, os elementos estão em contínua movimentação: "Para onde nossa vista se volta, vemos lentas ou rápidas mudanças da superfície da Terra. Firmes seguem os elementos inorgânicos e orgânicos de um lugar para outro; nada está em repouso e nada dura para sempre." (Walther 1894).
Os primeiros passos para a abordagem sistêmica, na concepção contemporânea do termo, foram dados entre as décadas de 1950 e 1970, com os trabalhos pioneiros que aplicavam os conceitos da mecânica newtoniana aos processos geomorfológicos (Huggett 2007). As forças representariam as interações entre os elementos, tais como rochas, solos, formas do relevo. Elas seriam os entes imateriais responsáveis por tornar os sistemas geomorfológicos algo maior do que a soma de seus elementos. De acordo com Huggett (2007),

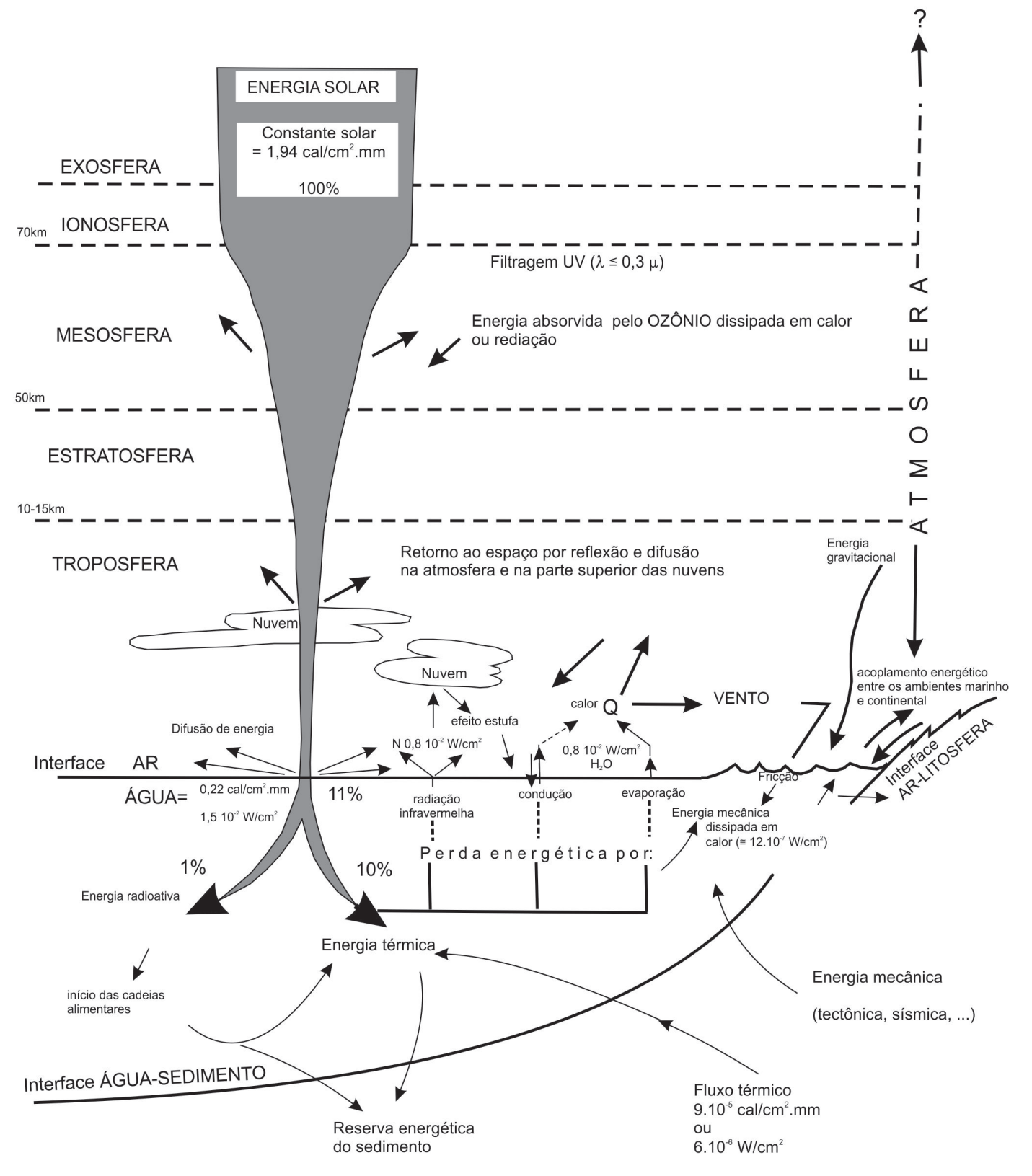

Figura 1. Esquema do fluxo energético no sistema bio-sedimentar, proposto por Humbert (1972). A figura foi editada na íntegra a partir do original, com livre tradução. 
a geomorfologia considera três tipos de sistemas: (i) sistemas morfológicos, que englobam as interrelações entre diferentes elementos em uma forma da paisagem, (ii) sistemas em cascata (ou de fluxo), representando os caminhos de transferência e armazenamento de massa e energia, que inclui o ciclo sedimentar, e (iii) sistemas de processo-forma, que nada mais são do que os dois primeiros numa relação de interdependência.

Humbert (1972) discutiu as possibilidades de aplicação da Teoria Geral do Sistema aos processos por ele chamados de bio-sedimentares. O autor descreveu com detalhes o fluxo de energia solar através da atmosfera, hidrosfera e dos sedimentos (Fig. 1). Na visão de Humbert (1972) o sistema bio-sedimentar seria composto de quatro subsistemas, (i) atmosfera, (ii) oceano, (iii) sedimentos, (iv) litosfera continental. Este trabalho pode ser considerado um marco na aplicação da teoria sistêmica aos processos geológicos de superfície. Apesar disso, sua abordagem praticamente não foi incorporada à sedimentologia moderna.

\section{O sistema sedimentar}

A sedimentação, enquanto processo global pode ser compreendida como um sistema, na acepção dada pela Teoria Geral do Sistema. É possível reconhecer na superfície da Terra inúmeros elementos, tais como fluidos, solos, sedimentos, íons dissolvidos, seres vivos e matéria orgânica em decomposição. Estes elementos interagem entre si por meio de processos mecânicos, químicos e metabólicos.

Enquanto sistema aberto, o sistema sedimentar prevê entrada e saída de massa e de energia. A movimentação tectônica da litosfera, produzindo áreas-fontes e bacias, cria um arcabouço geral do sistema e define uma via principal de transferência de massa. A massa, na forma de sedimento, fluido, íons e organismos, entra no sistema por intermédio de (i) intemperismo e erosão, (ii) precipitação, (ii) emissão de gases e partículas por vulcões e fumarolas, (iii) dissolução de gases atmosféricos na água e (iv) metabolismo dos seres vivos. A saída de massa se dá por de (i) incorporação do sedimento ao registro geológico, (ii) dissolução de $\mathrm{CaCO}_{3}$, (iii) evaporação, (iv) liberação de gases dissolvidos na água para a atmosfera, (v) decomposição da matéria orgânica, (vi) metabolismo dos seres vivos. A energia, por sua vez, entra no sistema como (i) energia calorífica do Sol (produzindo fotossíntese); (ii) energia potencial gravitacional, (iii) energia gravi- tacional da Lua e do Sol (produzindo as marés) e, (iv) reações químicas endotérmicas. A energia sai do sistema por meio de trabalho realizado pelos fluidos em movimento, liberação para a atmosfera de calor acumulado em corpos d'água e reações químicas exotérmicas.

O sistema sedimentar pode importar entropia negativa. Um fluido em movimento, em seu estado puro, apresenta um grau de complexidade dado pelas interações entre as suas moléculas com o substrato e com a atmosfera. Quando o fluido incorpora sedimentos, os componentes clásticos terrígenos contribuem com um maior grau de complexidade. Por exemplo, uma corrente de água pura - o caso extremo de fluxo fluido - é menos complexa e organizada do que um fluxo denso turbulento subaquoso particulado. Outra forma de incorporar entropia negativa é por meio do metabolismo dos seres vivos, produzindo moléculas orgânicas complexas.

O princípio da equifinalidade também pode ser reconhecido na busca da estabilidade, representado pela superfície equipotencial ou perfil de equilíbrio. Esta superfície representa a o perfil de maior eficiência no processo de transporte de sedimento das áreas altas para as áreas baixas. Porém, a superfície fisiográfica só atinge o perfil de equilíbrio localmente e por um curto intervalo do tempo geológico. A razão para isso reside no fato de que não é possível manter o equilíbrio entre soerguimento da área-fonte e subsidência da bacia. Por exemplo, em uma bacia de retroarco ou de antepaís periférica, a subsidência viscoelástica provocada pela sobrecarga tectônica é mais rápida do que a capacidade que os agentes da superfície têm de erodir a faixa de dobramentos e empurrões. Além de serem raras as condições de equilíbrio entre taxa de soerguimento e de erosão, o perfil de equilíbrio ainda depende de outros fatores, como a descarga fluvial e a carga sedimentar, tornando mínima a probabilidade de o sistema atingir o equilíbrio por um tempo considerável. Não obstante, o sistema busca constantemente atingir a situação de equilíbrio, mesmo que variem as condições iniciais. Por exemplo, em bacias hidrográficas de clima úmido, a descarga é alta; os processos erosivos são constantes, porém não muito rápidos, pois a vegetação atua no sentido de fixar o sedimento. Em clima árido, em contrapartida, a descarga é baixa, mas os processos erosivos, apesar de inconstantes, são intensos devido à falta de vegetação. Dessa forma, a finalidade de erodir, premente em uma determinada região, 


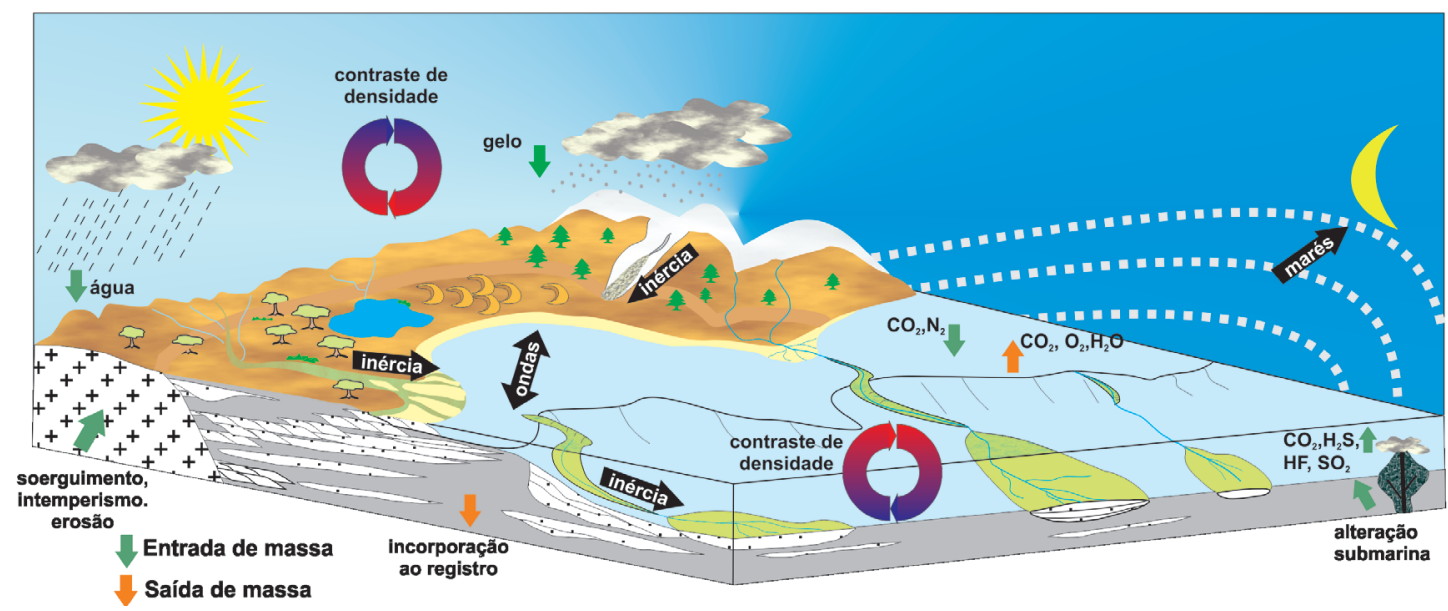

Figura 2. O sistema sedimentar.

é buscada pelo sistema, mesmo com a variação da entrada de água por precipitação.

A Figura 2 sintetiza a visão do sistema sedimentar apresentada acima. Adicionalmente, ela expressa a organização interna do sistema aqui proposta, baseada na natureza da energia dominante. São definidos assim subsistemas - aqui chamados de domínios - (i) de gravidade terrestre (inerciais), (ii) de contraste de densidade, (iii) de ondas e (iv) de marés. A cada domínio corresponderá uma ou mais feições fisiográficas, as quais estabelecem uma ligação entre si, que faz sentido por meio da visão sistêmica.

Ao longo deste artigo serão discutidos aspectos gerais do sistema, como a entrada e a saída de massa e energia e a transferência de massa. A transdisciplinaridade e a grande abrangência do tema tornam esta discussão muito mais ampla do que é possível apresentar aqui. O que se propõe a seguir é apresentar uma visão geral do fenômeno da sedimentação como um possível caminho didático-pedagógico a ser seguido nos cursos de geociências.

\section{Balanço de massa e energia}

As leis termodinâmicas da conservação afirmam que tudo o que entra em um sistema tem que sair, ser armazenado ou gerar transformações; matéria, energia e momento não podem aparecer ou desaparecer sem serem quantificadas; o balanço entre entrada e saída de massa pode ser formulado como

$$
d M / d t=M_{e}-M_{s},
$$

onde $M$ é a massa, $t$, o tempo, $e$, entrada e $s$, saída (Huggett 2007). Nesta seção serão enfocados os processos ligados a esses dois momentos relevantes do sistema sedimentar.

\section{Entrada de massa e energia}

A energia entra no sistema sedimentar a partir da força eletromagnética da radiação solar e da força gravitacional, esta última proveniente da própria Terra, como energia potencial gravitacional, ou da Lua e do Sol, como energia das marés. O trabalho realizado para gerar energia potencial gravitacional é produzido pelo movimento das placas tectônicas, o qual é resultado, em última análise, do calor do interior da Terra, cuja origem está no decaimento radioativo. A energia térmica interna também é uma fonte adicional de energia para o sistema sedimentar como, por exemplo, em vulcões, fumarolas e fontes quentes.

A entrada de massa se dá por meio da precipitação de chuva e neve, da surgência de água, do vulcanismo, do intemperismo das rochas e da fotossíntese. Sedimentos químicos, por sua vez, são precipitados na massa d'água, formando crostas junto ao substrato, lama em suspensão ou partículas. Compostos químicos são também secretados por organismos, em condições tanto subaéreas como subaquosas, e incorporados à sua estrutura; com a morte do organismo, estas estruturas transformam-se em partículas sedimentares.

Uma vez precipitada, a água e os íons nela dissolvidos passam a se infiltrar no solo, sendo uma parte absorvida pelas plantas, enquanto a outra parte alimenta o lençol freático, este último formando as nascentes das drenagens. O fluxo da água através do solo e das rochas até o freático contribui com 
o intemperismo químico. A água também pode escorrer diretamente sobre a superfície, promovendo a desagregação mecânica do solo e da rocha alterada. A neve que não derreter se acumula, podendo formar geleiras.

A água que alimenta o sistema também pode ter tido um longo tempo de residência em um aquífero e passado por um grande deslocamento vertical e horizontal. Estas águas afloram em determinados arranjos estruturais e estratigráficos e possuem características físico-químicas diferentes das águas superficiais. Em geral apresentam mais íons dissolvidos e temperaturas mais altas.

O vulcanismo, além de gerar rochas vulcânicas sujeitas ao intemperismo, também pode contribuir com a formação de sedimentos piroclásticos, que são incorporados diretamente ao sistema. É o caso das nuvens ardentes e da queda de cinza vulcânica. Além disso, o vulcanismo submarino libera para a água gases como $\mathrm{CO}_{2}, \mathrm{HCl}, \mathrm{HF}, \mathrm{SO}_{2}, \mathrm{H}_{2} \mathrm{~S}$ (Tardy 1987, Formoso 2006).

O sedimento siliciclástico é produzido a partir do intemperismo das rochas silicáticas, que são as mais abundantes na superfície terrestre (Gislason \& Oelkers 2011). As frações mais grossas são mais ricas em minerais instáveis, como os feldspatos, e a areia fina é enriquecida em quartzo, um mineral relativamente inerte. O intemperismo das rochas cristalinas máficas produz ainda argilominerais do grupo das esmectitas, e o das rochas graníticas, argilominerais do grupo das caulinitas e ilitas (Gislason \& Oelkers 2011).

Os sedimentos químicos são gerados por uma série de reações bióticas e abióticas, utilizando os íons disponíveis. Os íons, por sua vez, são oriundos do intemperismo, de fontes vulcânicas e hidrotermais e pela dissolução de sedimento, em um processo de reciclagem, e são incorporados a partir da atmosfera pela precipitação. A matéria orgânica, por sua vez, é produzida a partir de substâncias inorgânicas por meio da fotossíntese. Esses processos detalhados a seguir.

\section{Intemperismo, produção do sedimento siliciclástico e íons em solução}

O intemperismo pode ser físico, químico ou biogênico. O intemperismo físico é o mais primário, pois depende apenas da radiação solar, estando presente em outros planetas rochosos, mesmo que não haja água nem vida presentes.

O intemperismo físico é basicamente produ- zido por mudanças contínuas de volume sofridas pelas rochas, provocadas por oscilações termais. As rochas são aquecidas pelo Sol e se dilatam e, à noite, elas esfriam e se contraem. Esta deformação contínua provoca a ruptura da rocha em planos de fraqueza inerentes ao material (Fig. 3), favorecendo a infiltração de água e o intemperismo químico, desagregando as rochas em blocos. Outra forma de intemperismo físico ocorre em clima frio, quando a água que se infiltra na rocha congela, aumentando de volume e forçando a abertura de juntas.

Levando-se em consideração um período mais longo, a formação de juntas que favorecem o intemperismo físico também ocorre quando há o soerguimento de uma camada de rocha, a qual se expande junto à superfície (Price 1966, Bridge \& Demicco 2008).

O intemperismo químico ocorre por meio de reações de minerais das rochas com a água e os íns por ela carregados. A água da chuva, ao atingir o solo, já possui íons dissolvidos, tais como $\mathrm{Na}^{+}$, $\mathrm{Cl}^{-}, \mathrm{NO}_{3}^{-}, \mathrm{HCO}_{3}^{-}$, e partículas de minerais. Estes compostos são originários de aerossóis de água do mar, poeira e dos próprios gases atmosféricos (Bridge \& Demicco 2008). Destes, o gás carbônico da atmosfera, dissolvido na forma de $\mathrm{HCO}_{3}^{-}$, é o mais importante para as reações com os minerais das rochas, tornando levemente ácida a água da chuva. Essas reações produzem íons, que são transportados pela água, ou minerais de alteração mais facilmente removidos da rocha ou do solo por processos mecânicos, tais como os argilominerais.

De acordo com Formoso (2006), o processo de intemperismo químico compreende a transformação de estruturas mineralógicas complexas em

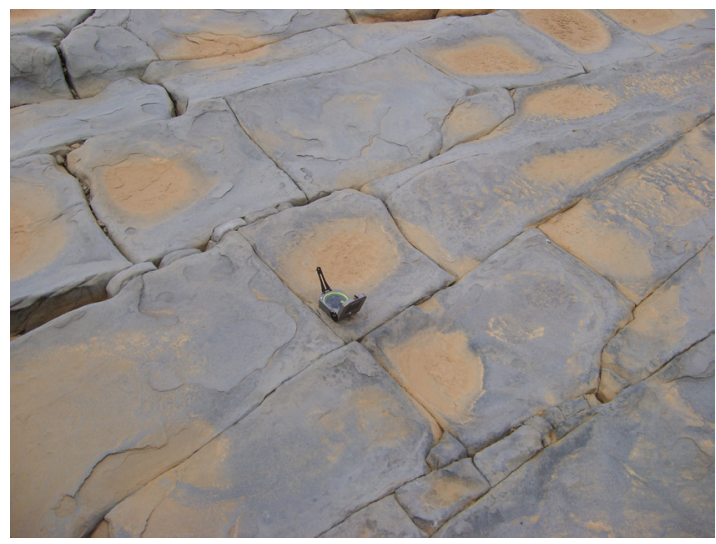

Figura 3. Fraturas ortogonais em arenito provocadas por alternância de aquecimento e esfriamento em clima semiárido (Formação Skoorstenberg, Permiano Superior, Bacia do Karoo, África do Sul). 
outras mais simples, e a neoformação de minerais estáveis nas condições superficiais de temperatura e pressão, como caulinita, goethita, hematita, gibbsita e boehmita. Ainda segundo Formoso (2006), a transformação química mais importante no intemperismo é a hidrólise de silicatos, como no exemplo do feldspato potássico:

$$
\begin{aligned}
& 2 \mathrm{KAlSi}_{3} \mathrm{O}_{8(s, c)}+11 \mathrm{H}_{2} \mathrm{O}_{(l)}=4 \mathrm{H}_{4} \mathrm{SiO}_{4(a q)}+ \\
& \mathrm{Al}_{2} \mathrm{Si}_{2} \mathrm{O}_{5}(\mathrm{OH})_{4(s, c)}+2 \mathrm{~K}_{(a q)}^{+}+2 \mathrm{OH}_{(a q)}^{-}
\end{aligned}
$$

onde $\mathrm{s}=$ sólido, $\mathrm{c}=$ cristalino, $1=$ líquido $\mathrm{e}$ $\mathrm{aq}=$ aquoso. Nesta reação a caulinita é cristalizada e a sílica restante é solubilizada- representada na reação pelo ácido ortossilícico - o cátion potássio e o ânion hidroxila. Reações deste tipo produzem a camada de alterito, constituída pelos minerais supergênicos e os minerais primários relictos (Formoso 2006). Acima dessa camada situa-se o solo, onde a atividade biológica é maior.

A alteração de rochas graníticas e sedimentares sobre os continentes implica em consumo de gás carbônico e liberação de íons $\mathrm{Ca}^{2+}, \mathrm{Mg}^{2+}, \mathrm{Na}^{+}, \mathrm{K}^{+}$, e $\mathrm{HCO}_{3}^{-}$, os quais terminam por chegar ao oceano (Tardy 1987).

A água meteórica levemente ácida também provoca a dissolução das rochas carbonáticas, colo-

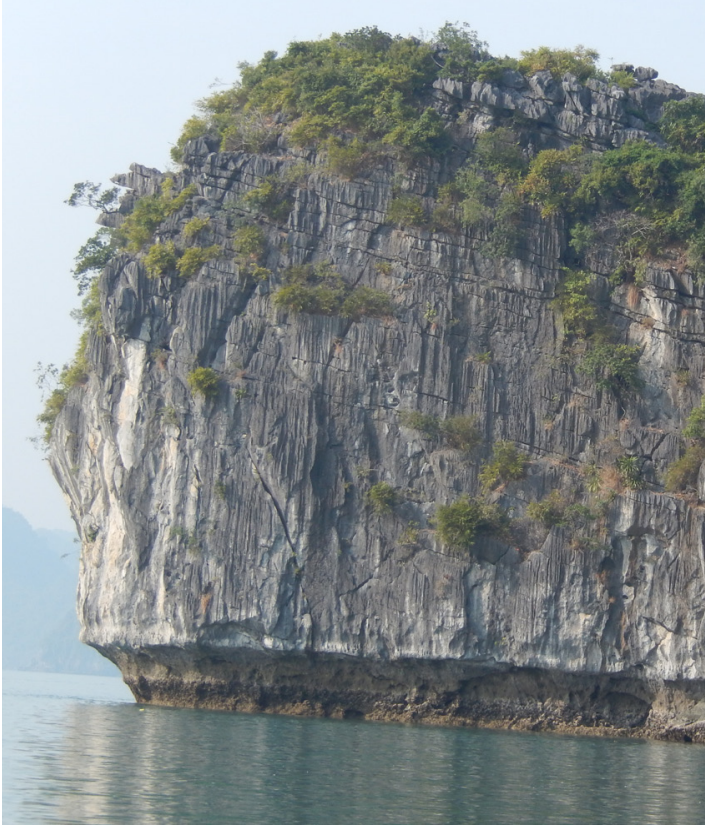

Figura 4. Rochas carbonáticas paleozoicas submetidas a intemperismo químico. A intensa dissolução mantém preservados pináculos isolados de rocha. Baía Ha Long, Vietnã. cando em solução os íons $\mathrm{Ca}^{2+} \mathrm{e} \mathrm{CO}_{3}^{2-}$, produzindo assim o relevo kárstico característico deste tipo de rocha e fornecendo íons ao sistema sedimentar (Fig. 4). O intemperismo da calcita, por exemplo, ocorre com consumo de $\mathrm{CO}_{2}$, liberando íons de cálcio e bicarbonato em solução (Tardy 1997).

De acordo com Humbert (1972), um solo tende a se manter num estado estacionário, sempre reconstituindo o seu perfil, no sentido inverso da erosão e da lixiviação; isto gera uma ordem de liberação de elementos para os fluidos superficiais. Este estado, no entanto, sempre é passível de ser rompido, como quando processos erosivos ou de inundação atuam numa taxa maior do que a velocidade de recuperação do solo.

Nos oceanos, é importante também o processo de alteração dos basaltos da crosta oceânica, por meio do qual ocorre a troca entre o cálcio das rochas com o magnésio da água, produzindo $\mathrm{CO}_{2}$ (Tardy 1987, 1997). O intemperismo de minerais e vidro de rochas basálticas em ilhas oceânicas é uma grande fonte de sedimento e íons para a água dos oceanos (Gislason \& Oelkers 2011). A água dos oceanos e de corpos d'água menores também recebe elementos na forma dissolvida ou particulada, em grande parte oriundos do continente e transportados pelos dos rios como, por exemplo, o cálcio (Gislason \&Oelkers 2011). Este fator é fundamental para a precipitação de sedimentos químicos.

A terceira forma de intemperismo é a biogênica. Considera-se biogênico porque são processos induzidos por seres vivos; no entanto, esses processos não deixam de ser físicos ou químicos em sua essência. As raízes das plantas podem penetrar nas fraturas das rochas, acelerando a sua desagregação em blocos. Os seres vivos que se fixam nas rochas também podem secretar substâncias químicas que aceleram o intemperismo físico. Essas substâncias podem ser simplesmente um sub-produto do organismo, como o caso dos ácidos orgânicos produzidos pelos líquens. No entanto, o ecossistema como um todo faz uso desse processo no sentido de criar um ambiente físico-químico cada vez mais favorável à colonização de seres vivos, num sentido que vai da rocha ao solo. Há muitos casos em que o organismo deliberadamente desagrega a rocha para facilitar a sua fixação e para criar abrigos (Fig. 5).

Nos solos ocorre a produção de ácidos orgânicos pela ação das raízes das plantas e da decomposição bacteriana de matéria orgânica, e esses ácidos reagem com os silicatos, conforme explanado por Formoso (2006), como segue. Um ácido orgânico 


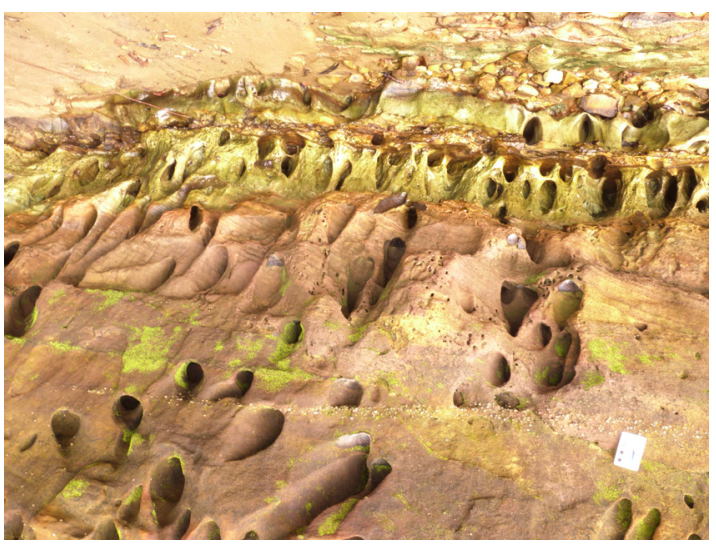

Figura 5. Escavações em arenito da Fm. Maecuru (Devoniano da Bacia do Amazonas), produzidas por peixes nos períodos de cheias, com finalidade de proteção. Rio Tapajós, próximo a Vila Rayol (PA).

como o ácido oxálico, por exemplo, se dissocia em meio aquoso, formando íons $\mathrm{H}^{+}$e ânions oxalato:

$$
\mathrm{H}_{2} \mathrm{C}_{2} \mathrm{O}_{4(a q)}=2 \mathrm{H}_{(a q)}^{+}+\mathrm{C}_{2} \mathrm{O}_{4}^{2-}{ }_{(a q)} .
$$

$\mathrm{O}$ íon $\mathrm{H}^{+}$reage com um alumino-silicato, por exemplo, dissociando-o:

$$
\begin{gathered}
\mathrm{H}_{(a q)}^{+}+4 \mathrm{H}_{2} \mathrm{O}_{(l)}+\text { silicato }=\mathrm{Al}_{(a q)}^{3+}+ \\
\text { metal }_{(a q)}^{n+}+\mathrm{mH}_{4} \mathrm{SiO}_{4(a q)} .
\end{gathered}
$$

O oxalato reage com o cátion alumínio formando um quelato:

$$
\mathrm{Al}^{3+}{ }_{(a q)}+\mathrm{C}_{2} \mathrm{O}_{4}^{2-}(a q)=\mathrm{Al}\left(\mathrm{C}_{2} \mathrm{O}_{4}\right)_{(a q)}^{+}
$$

A atividade bacteriana então decompõe o quelato, oxidando o oxalato e liberando $\mathrm{Al}^{3+}$, que precipita como hidróxido ou argilominerais.

\section{Erosão}

O solo se torna sedimento a partir do momento em que é erodido. De acordo com Schumm (1977), em geomorfologia utiliza-se um modelo de ciclo erosivo relativamente simples, proposto em 1899 por Davis. Este modelo sugere que um curto intervalo de soerguimento é seguido por um longo período de denudação do terreno (Fig. 6).

O que define se um determinado terreno será erodido é o perfil de equilíbrio, o qual também controlará onde e quando haverá deposição. De acordo com Mackin (1948), o conceito de uma superfície de equilíbrio é fundamental para as geociências; no entanto, o equilíbrio propriamente dito - ou estabilidade, por serem sistemas abertos - é inatingível, porque os canais apresentam grande instabilidade, mesmo quando se considera um curto intervalo de tempo, devido às variações sazonais de descarga. Assim, o estilo do perfil de equilíbrio pode variar, como nos casos de "equilíbrio dinâmico" ou de "metaestabilidade" (Fig. 7).

O conceito de perfil de equilíbrio é um dos mais importantes para a abordagem sistêmica da sedimentação. A superfície ideal é dada pela altura em que o sistema apresenta a maior eficiência na transferência de massa e de energia em cada trecho. Quando a superfície real está acima deste nível, os processos intrínsecos ao sistema sedimentar atuam, por meio da erosão, para que esta superfície seja alcançada. Ao contrário, quando o terreno está abaixo do perfil, os processos do sistema atuam de modo a atingi-lo utilizando-se da deposição de sedimento.

Os diferentes estilos de perfil mostrados na Figura 7 resultam de diferentes taxas de subsidência ou de soerguimento. Elas podem ser lentas o suficiente para a superfície do terreno se ajustar facilmente ao perfil, o que é chamado de equilíbrio variável, ou tão rápidas que a superfície do terreno só volta a se ajustar após um longo período (Mackin 1948).

Os principais fatores que controlam a declividade do perfil de equilíbrio são a descarga e a carga sedimentar, uma vez que elas condicionam as características e a eficiência hidráulica do sistema (Mackin 1948, Langbein \& Schumm 1958, Bridge \& Leeder 1979, Schumm 1993, Berendsen \& Stouthamer 2000). O nível de base geomorfológico - nível relativo do mar ou de um lago - também

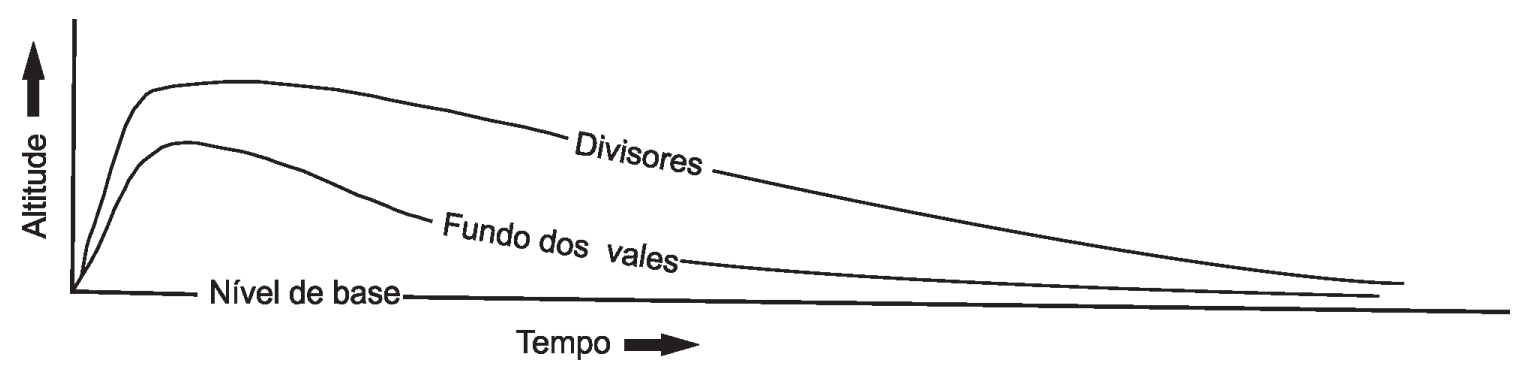

Figura 6. Modelo de Davis para o ciclo geomorfológico. Modificado de Schumm (1977). 


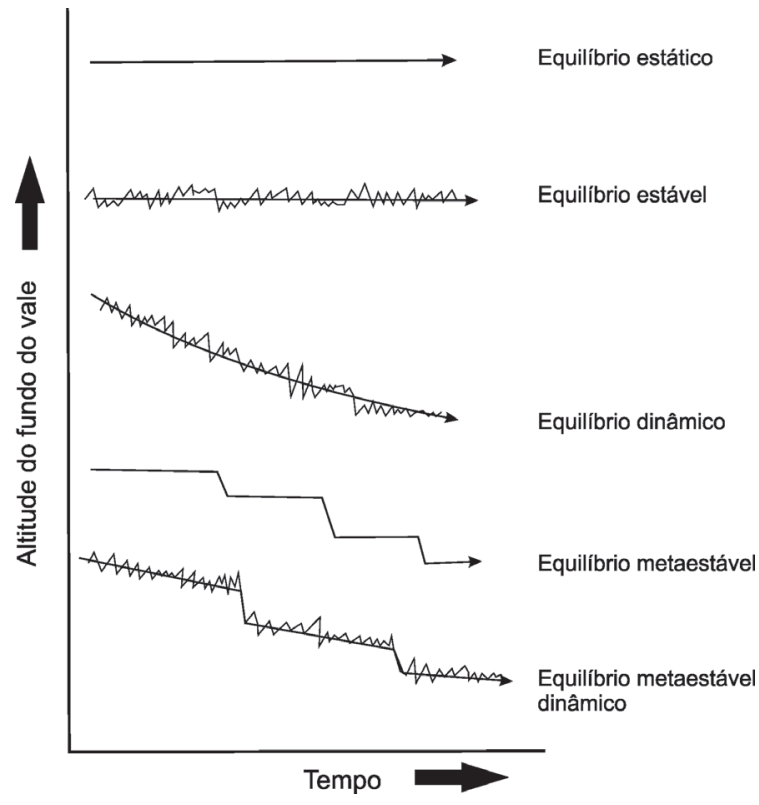

Figura 7. Comportamento da superfície do terreno ao longo do tempo. (A) Estado estático, sem mudança ao longo do tempo. (B) Equilíbrio estável: variações sobre um padrão médio constante (tempo graduado). (C) Equilíbrio dinâmico: variações ao longo de uma condição média (tempo cíclico). (D) Equilíbrio metaestável: equilíbrio estático separado por episódios de erosão. (E) Equilíbrio dinâmico metaestável: equilíbrio dinâmico com erosões episódicas (modificado de Schumm 1977). A nomenclatura utilizada é oriunda da Geomorfologia; os termos foram mantidos, apesar de diferirem daqueles utilizados na Teoria Geral do Sistema para descrever um sistema aberto.

exerce influência sobre o perfil de equilíbrio, porém atuando sobre uma área restrita às regiões costeiras (Schumm 1993).

Em termos práticos, o perfil de equilíbrio também chamado de nível de base estratigráfico condiciona se uma determinada área estará sujeita e processos erosivos ou deposicionais. Este conceito foi desenvolvido para bacias fluviais, e permite explicar a deposição acima do nível de base geomorfológico, sempre que o terreno estiver em um nível abaixo do perfil de equilíbrio.

Em um desdobramento mais moderno do conceito, o perfil de equilíbrio também poderia explicar porque há erosão abaixo do nível do mar. Neste sentido, Kneller (2003) discorreu sobre a aplicação desse conceito para a sedimentação em águas profundas, nos canais e lobos submarinos. De acordo com o autor supracitado, nessas regiões o perfil de equilíbrio seria controlado pelas dimensões, densidade e tamanho de grão dos fluxos subaquosos.

Outros fatores determinam a intensidade da erosão, como a densidade da vegetação, a pluviosidade e o grau de alteração do substrato. A erosão pode ser realizada por diferentes agentes, tais como correntes canalizadas, vento e gelo (Fig. 8). Em última análise, o substrato é erodido e o sedimento é transportado pela propriedade que os fluidos têm de gerar atrito, o chamado processo de abrasão.

\section{Síntese do sedimento químico}

\section{Sedimentos carbonáticos}

Os sedimentos carbonáticos de águas rasas são produzidos por uma série de processos bióticos e abióticos gerando partículas e bioconstruções. Por sua vez, os sedimentos carbonáticos de águas profundas são produzidos pela chuva de carapaças de microorganismos calcários, que ficarão preservadas se o fundo da bacia estiver acima da zona de compensação de carbonato (Schneider et al. 2000). De acordo com Milliman (1993), as principais fontes de cálcio para as bacias marinhas são os rios, fontes hidrotermais e águas subterrâneas, sendo os primeiros os que contribuem com o maior volume dissolução de carbonato na água, por sua vez, é definida pelos níveis de saturação de calcita e ara-
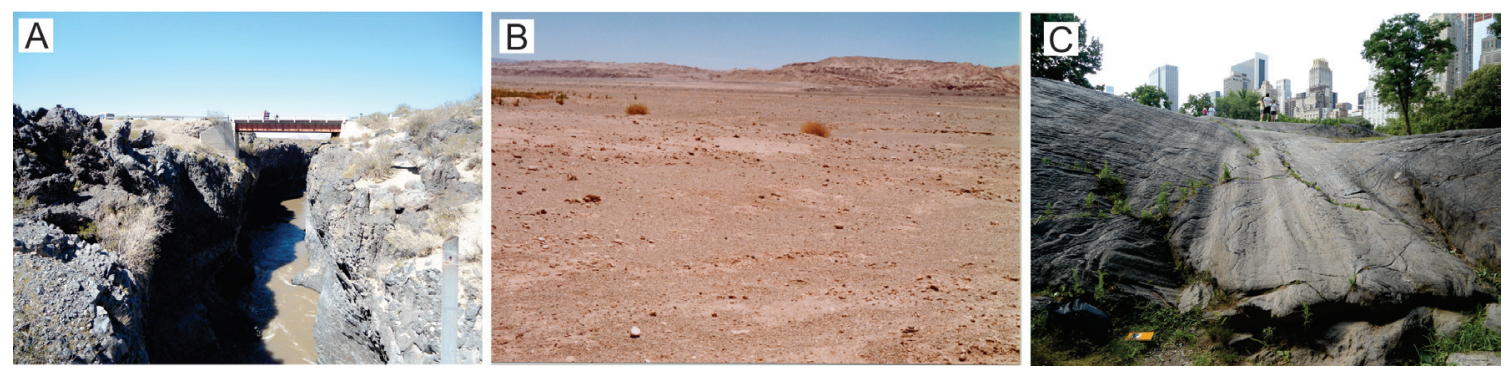

Figura 8. Resultados de processos de abrasão. (A) Canal do Rio Grande (Neuquén, Argentina) escavando derrames basálticos que se interpuseram ao seu curso no Quaternário. (B) Superfície de deflação eólica, formada pela ablação do vento, removendo grãos menores e abrasando os seixos e a superfície do terreno (Deserto do Atacama, Chile). (C) Trilha estriada (roche moutonnée) sobre gnaisse, formada pelo atrito do gelo, que se movera durante a Glaciação Wisconsiniana (há cerca de 75.000 anos) (Central Park, New York City, EUA). 
gonita, os quais são controlados pelas condições de temperatura, pressão, $\mathrm{pH}$ e alcalinidade das massas d'água (Schneider et al. 2000).

Schneider et al. (2000) apresentaram a sequência de reações que produzem o carbonato na água, como será mostrado a seguir, de forma resumida. Em contato com a atmosfera, a pressão parcial de gás carbônico $\left(p \mathrm{CO}_{2}\right)$ determina a concentração de ácido carbônico em solução, de acordo com a equação

$$
\mathrm{CO}_{2(g)}+\mathrm{H}_{2} \mathrm{O} \leftrightarrow \mathrm{H}_{2} \mathrm{CO}_{3(a q)}{ }^{0} .
$$

O complexo aquoso produzido é dissociado em prótons e íons bicarbonato,

$$
\mathrm{H}_{2} \mathrm{CO}_{3(a q)}^{0} \leftrightarrow \mathrm{H}^{+}+\mathrm{HCO}_{3}^{-} .
$$

O segundo passo da dissociação é enunciado como

$$
\mathrm{HCO}_{3}^{-} \leftrightarrow \mathrm{H}^{+}+\mathrm{CO}_{3}{ }^{2-} .
$$

O processo de precipitação e dissolução de calcita sólida é dado pela reação reversível

$$
\mathrm{CaCO}_{3 \text { (calcita) }} \leftrightarrow \mathrm{Ca}^{2+}+\mathrm{CO}_{3}{ }^{2-} .
$$

O carbono utilizado na produção de carbonatos também pode ser disponibilizado a partir da dissolução de cristais e carapaças compostas por esses minerais, bem como da respiração e da oxidação de matéria orgânica, sem a participação do gás carbônico atmosférico (Schneider et al., 2000). Além disso, desempenha um papel muito importante a liberação de gás carbônico e íons cálcio pelo vulcanismo, tanto subaéreo como subaquoso, sendo que na história da Terra, os períodos com maior produção de rochas sedimentares carbonáticas são também os de maior produção de rochas vulcânicas (Tardy 1987). De acordo Tardy (1987), a alteração hidrotermal de rochas vulcânicas nas dorsais oceânicas produz argilominerais magnesianos (fórmula geral $\mathrm{MgSiO}_{3}$ ) e calcita, além de liberar gás carbônico, conforme a reação esquemática:

$$
\begin{aligned}
& \mathrm{CaSiO}_{3}+\mathrm{Mg}^{2+}+2 \mathrm{HCO}_{3}^{-} \rightarrow \mathrm{MgSiO}_{3} \\
& \quad+\mathrm{CaCO}_{3}+\mathrm{CO}_{2}+\mathrm{H}_{2} \mathrm{O} .
\end{aligned}
$$

As partículas sedimentares carbonáticas produzidas em águas rasas são representadas pelos ooides e agulhas de aragonita, os primeiros formados por processos abióticos, e as últimas tanto por processos abióticos quanto bióticos (Schneider et al. 2000). Os recifes hermatípicos, produzidos principalmente por corais e algas verdes, são os principais produtores de carbonato na atualidade (Schneider et al. 2000). Nas plataformas, o carbonato é produzido de forma biótica, por algas vermelhas/verdes bentônicas, moluscos e foraminíferos bentônicos e, num menor grau, por processos abióticos (Schneider et al. 2000).

De acordo com Erez (2003), o maior volume de sedimento carbonático é produzido por processos biogênicos, entre os quais a fotossíntese. Dessa forma, o autor enuncia a sequência de reações como:

$$
\begin{gathered}
\mathrm{Ca}^{2+}+2 \mathrm{HCO}_{3}^{-} \rightarrow \mathrm{CaCO}_{3}+\mathrm{H}_{2} \mathrm{O}+ \\
\mathrm{CO}_{2} \rightarrow \mathrm{CaCO}_{3}+\mathrm{CH}_{2} \mathrm{O}+\mathrm{O}_{2} .
\end{gathered}
$$

De fato, os principais organismos calcificadores ou são fotossintetizantes pela sua natureza, como as algas calcárias, ou possuem simbiontes fotossintetizantes, como os corais hermatípicos e a maioria dos foraminíferos. A calcificação ocorre principalmente nas águas superficiais, mas as carapaças se depositam no fundo, por ação da gravidade (Erez 2003). Segundo o autor, a dissolução de carbonato também é um processo fortemente ligado ao metabolismo orgânico, na forma da oxidação da matéria orgânica por meio da respiração, de acordo com a sequência de reações:

$$
\begin{gathered}
\mathrm{Ca}^{2+}+2 \mathrm{HCO}_{3}^{-} \leftarrow \mathrm{CaCO}_{3}+\mathrm{H}_{2} \mathrm{O}+ \\
\mathrm{CO}_{2} \leftarrow \mathrm{CaCO}_{3}+\mathrm{CH}_{2} \mathrm{O}+\mathrm{O}_{2} .
\end{gathered}
$$

O mecanismo pelo qual os organismos produzem estruturas carbonáticas está além do escopo deste trabalho. No entanto, a título de exemplo da complexidade do processo, menciona-se resumidamente o caso dos foraminíferos, o grupo que produz o maior volume de carbonato nos oceanos. Nos foraminíferos de parede porcelânica a cristalização de hastes de calcita magnesiana ocorre em vacúolos do citoplasma e, posteriormente esses cristais são deslocados para o local de construção da carapaça e arranjados de forma aleatória (Hansen 2002, Erez 2003, Nooijer et al. 2009) (Fig. 9B). Os foraminíferos de parede calcária hialina (que permite a passagem da luz) armazenam o cálcio e o carbonato em depósitos intracelulares distintos (Nooijer et al. 2009) (Fig. 9A). Inicialmente, o volume da nova câmara é isolado com o auxílio dos pseudópodes ectoplasmáticos e posteriormente um molde orgânico é construído na forma da nova câmara; o carbonato, em forma de calcita ou aragonita é, então, precipitado dos dois lados de uma fina camada orgânica; uma camada secundária de carbonato é ainda depositada no lado externo da 


\section{B Calcificação dos miliolídeos}
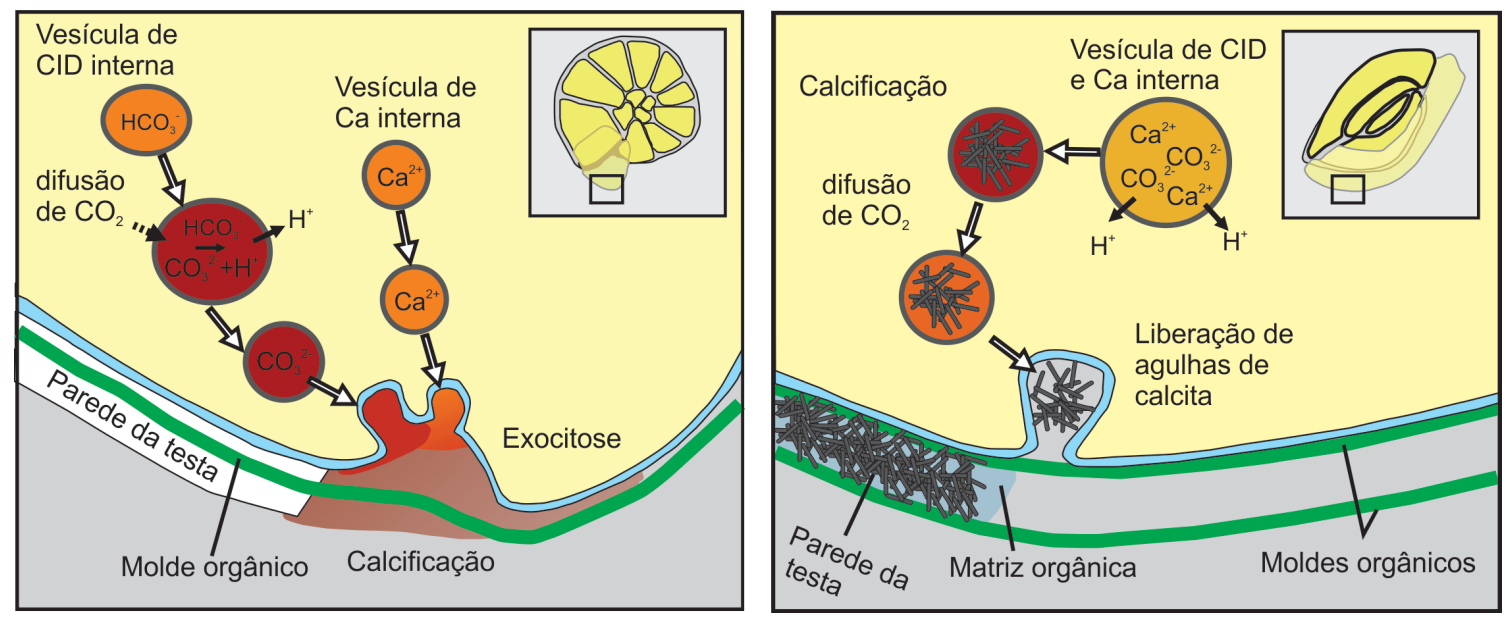

Figura 9. Mecanismos de construção da testa de foraminíferos bentônicos (A) calcários hialinos (parede perfurada) e (B) miliolídeos (parede porcelânica). Modificado de Nooijer et al. (2009)

testa, conferindo-lhe uma estrutura em camadas (Hansen 2002, Erez 2003, Nooijer et al. 2009). Para precipitar $\mathrm{CaCO}_{3}$, o organismo desenvolve vesículas com alto $\mathrm{pH}$, e transporta este material alcalino até o local da precipitação do carbonato (Nooijer et al. 2009).

\section{Sedimentos silicáticos}

Um importante grupo de organismos marinhos possui esqueleto de sílica. Os principais representantes desse grupo são as diatomáceas, radiolários, e secundariamente, os silicoflagelados. Esses organismos utilizam a sílica dissolvida como um nutriente essencial e, frequentemente, limitante ao seu desenvolvimento (DeMaster 1981). A biota silicática remove quase todo o silício dissolvido das águas superficiais do oceano.

A produção de sílica biogênica nas águas superficiais depende da disponibilidade de nutrientes e da quantidade de silício dissolvido. Após a morte da biota o material silicático dos esqueletos se dissolve na medida em que afunda na coluna d'água, enriquecendo as águas profundas em sílica dissolvida (DeMaster 1981). Posteriormente estes fragmentos se depositam no fundo, podendo sofrer dissolução na interface água-sedimento ou ser preservados nos sedimentos.

Nelson et al. (1995) estimam que a produção de sílica biogênica - também denominada opala - no oceano oscila entre $200-280 \times 10^{12} \mathrm{~mol} / \mathrm{ano}$. Segundo os autores, ao menos $50 \%$ da sílica produzida por diatomáceas na zona eufótica é dissolvida nos primeiros 100 metros da coluna d'água, resultando na exportação de $100-140 \times 10^{12} \mathrm{~mol} /$ ano para o oceano profundo. No entanto, apenas uma pequena fração da sílica biogênica produzida é removida da coluna d'água pelo soterramento (Cappellen et al. 2002). Essa remoção é compensada pelo suprimento de sílica para o oceano pelos rios e da interação entre a água do mar e os basaltos submarinos.

Segundo estimativas de Takahashi (1991) apud Boltovskoy \& Pujana (2007), apenas a décima parte da sílica biogênica que chega ao fundo marinho se preserva no registro fóssil. Com o passar do tempo (40 a $60 \mathrm{Ma}$ ), a sílica biogênica amorfa, que é um composto solúvel e instável, tende a se transformar em calcedônia e ou quartzo (Boltovskoy \& Pujana 2007). A sílica biogênica também poder ser substituída por outros minerais tais como calcita, pirita, esmectita, zeolita e rodocrosita.

Algumas regiões dos oceanos apresentam conteúdo extremamente alto de opala, tais como os locais de concentração de vasas silicosas (Leinen et al. 1980). O Mar de Bering, por exemplo, apresenta um alto conteúdo de opala de diatomáceas enquanto no Pacífico as vasas são principalmente de radiolários. De um modo geral, o conteúdo de opala é maior no Pacífico do que no Atlântico.

\section{Sedimentos evaporíticos}

Evaporito é um termo genérico para designar depósitos de minerais que são sais muito solúveis, e que se precipitam em soluções hipersalinas. Para que esta condição seja atendida, a bacia deve apresentar um grau de isolamento, como lagos, lagunas e planícies de maré, e a taxa de evaporação deve exceder a de evaporação (Fig. 10). Mohriak et al. 


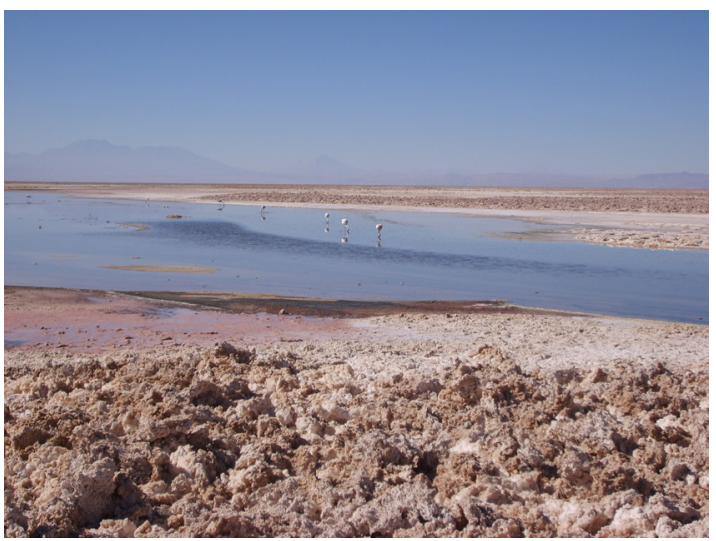

Figura 10. Crostas evaporíticas no Salar do Atacama, Chile, um exemplo de bacia evaporítica continental

(2008) apresentam uma síntese das principais bacias evaporíticas atuais, que tem em comum o fato de estarem em regiões de clima árido e serem corpos d'água fechados (Mar Morto, Salar de Uyuni) ou com comunicação restrita com um mar ou oceano (Afar, Golfo Pérsico, Golfo de Kara Bogaz).

Os evaporitos são depósitos de sais, que por sua vez são compostos por íons que possuem baixo potencial iônico (resultado da carga elétrica pequena e grande raio iônico), resultando numa alta solubilidade (Mohriak \& Szatmari 2008). Isto faz com que os minerais que compõem os evaporitos sejam os primeiros a serem colocados em solução e os últimos a serem precipitados num corpo d'água.

Entre os principais minerais evaporíticos estão a halita $(\mathrm{NaCl})$, silvita $(\mathrm{KCl})$, anidrita $\left(\mathrm{CaSO}_{4}\right)$, gipsita $\left(\mathrm{CaSO}_{4} \cdot \mathrm{H}_{2} \mathrm{O}\right)$, carnalita $\left(\mathrm{KMgCl}_{3} \cdot 6 \mathrm{H}_{2} \mathrm{O}\right)$, bischofita $\left(\mathrm{MgCl}_{2} \cdot 6 \mathrm{H}_{2} \mathrm{O}\right)$ e a taquidrita $\left(\mathrm{CaMg}_{2} \mathrm{Cl}_{6} \cdot 12 \mathrm{H}_{2} \mathrm{O}\right)$ (Tardy 1987, Mohriak \& Szatmari 2008). Esses minerais se cristalizam a partir de salmouras, que são soluções aquosas com teor de íons de sal superior a $1 \mathrm{~g} / 1$ (Mohriak \& Szatmari 2008). A composição da salmoura é distinta em bacias evaporíticas continentais e marinhas. As bacias continentais apresentam uma maior variabilidade de sais precipitados, além de serem magnesianas e pobres em sulfato, enquanto que as salmouras oriundas da água do mar são ricas em sulfato (Kendall 1992).

Em uma salmoura que perde água continuamente por evaporação, existe uma sequência de precipitação de minerais, dos menos solúveis para os mais solúveis, o que se reflete na variação lateral e na sucessão estratigráfica das fácies de evaporitos. De acordo com Mohriak \& Szatmari (2008), os primeiros a se precipitar são os carbonatos que, embora não sejam propriamente evaporitos, antecedem a sua deposição e estão comumente associados. Ainda segundo esses autores, seguem-se os sulfatos (gipsita e anidrita) e cloretos (halita, carnalita, bischofita e taquidrita). Para que se tenha ideia da variação de concentração da salmoura durante a precipitação da sequência exposta acima, consideremos $1.000 \mathrm{~g}$ de água do mar. A gipsita, primeiro mineral evaporítico da sequência, precipita-se quando a solução tiver sua massa reduzida a $322 \mathrm{~g}$, a halita a $121 \mathrm{~g}$ e a carnalita a $11,8 \mathrm{~g}$, pouco mais de $1 \%$ da massa da solução original (Mohriak \& Szatmari 2008).

Como exemplo de reação química de precipitação em uma salmoura, Tardy (1987) apresenta a formação da gipsita a partir dos íons cálcio e sulfato:

$$
2 \mathrm{H}_{2} \mathrm{O}+\mathrm{Ca}^{2+}+\mathrm{SO}_{4}^{2-} \rightarrow \mathrm{CaSO}_{4} \cdot 2 \mathrm{H}_{2} \mathrm{O} .
$$

\section{Precipitados metálicos}

A precipitação de metais na forma de óxidos, hidróxidos e sulfetos é outro processo de sedimentação química importante. Do ponto de vista geológico, os depósitos mais famosos são as formações ferríferas bandadas, responsáveis pelos maiores volumes de minério de ferro da Terra. São depósitos restritos ao Arqueano e Paleoproterozoico, formados em bacias primitivas com grande atividade vulcânica e hidrotermal (cf. Condie 1997) e seu processo de formação é controverso, em especial se houve ou não a participação de organismos. Além disso, acredita-se que a atmosfera possuía teores de oxigênio muito inferiores aos atuais, permitindo assim a sedimentação de minerais compostos pela forma reduzida do ferro. Por isso, nessa discussão sobre o sistema sedimentar estes depósitos não serão abordados. Ao se analisar a sedimentação atual, percebe-se que depósitos metálicos se formam nas bacias oceânicas.

Minerais metálicos se formam no fundo oceânico, em especial na forma de nódulos. Muito importantes são os nódulos de ferro e manganês que, segundo Bonatti \& Nayudu (1965), foram descobertos no século XIX por Murray e Renard, da expedição Challenger. Em regiões com baixas taxas de sedimentação, os nódulos, com forma e tamanho semelhante a batatas e laminação interna concêntrica, recobrem densamente o substrato macio; onde o substrato é duro, formam-se crostas (Riemann 1983). Sua composição é majoritariamente de oxi-hidróxidos de manganês e ferro, em razões muito variáveis, além de pequenas quantidades de cobre e níquel (cerca de 1\%) e, no caso das crostas, também cobalto, platina, tântalo e telúrio (Riemann 1983, 
Palma \& Pessanha 2000; Martins et al. 2006).

A fonte dos elementos metálicos e seu processo de incorporação aos nódulos é um tema muito debatido. De acordo com Bonatti \& Nayudu (1965), os metais poderiam ser provenientes dos continentes, por meio da descarga fluvial, ou do vulcanismo submarino. Os autores defenderam a última hipótese, e sugeriram um processo de alteração submarina de rochas vulcânicas lixiviando os metais e disponibilizando-os para o sistema sedimentar. Lyle (1982) considerou sua origem tanto na diagênese de sedimentos, como nos detritos orgânicos. Outra hipótese foi formulada por Riemann (1983), segundo a qual os metais seriam precipitados por meio de processos digestivos de foraminíferos bentônicos e de poliquetas que se alimentam dos primeiros.

Segundo Palma \& Pessanha (2000), em tempos mais recentes os estudos das grandes acumulações de nódulos nas bacias marinhas tem apontado para múltiplas fontes, sedimentares, vulcânicas e biogênicas. Por exemplo, na Bacia Central Indiana, a fonte parece ser sedimentar, com origem na grande descarga dos rios Ganges e Brahmaputra. Por outro lado, a Bacia do Peru coincide com uma zona de ressurgência, onde a produtividade nas águas superficiais é muito alta, e os organismos planctônicos devem ter um papel preponderante para a concentração de metais. Já a província de nódulos Clarion-Cipperton, no Pacífico Norte, tem a fonte dos metais atribuída tanto aos rios que desaguam na costa oeste da América do Norte, como ao vulcanismo da Cadeia do Pacífico Oriental (cf. Palma \& Pessanha 2000).

Os processos de formação dos depósitos marinhos de manganês e ferro são descritos por Palma \& Pessanha (2000), sendo aqui resumidos. Há três processos de precipitação desses metais, precipitação hidrogênica, diagênese óxica e diagênese subóxica. No primeiro deles, os metais em solução na água ou adsorvidos na superfície de partículas são incorporados diretamente aos nódulos e crostas. Já os processos diagenéticos dependem em grande parte da ação de organismos. O manganês e o ferro em solução na água são inicialmente incorporados aos organismos planctônicos ou concentrados em peloides fecais. Outros metais, como níquel e cobre, são retirados da água e incorporados a complexos orgânicos durante a passagem de restos orgânicos pela coluna d'água. No leito do oceano, os peloides fecais são digeridos por organismos bentônicos, que liberam os metais como cátions divalentes. Ao final do processo de diagênese óxica, os metais oriundos dos peloides e dos restos de organismos mortos, depositados no fundo, são incorporados aos nódulos por oxidação e adsorção. A diagênese subóxica é bastante similar, porém neste caso os nódulos estão recobertos por sedimento, ocorrendo então redução e remobilização do manganês.

Outro tipo de depósito metálico do fundo marinho que tem recebido atenção são os sulfetos polimetálicos, em especial na Elevação do Pacífico Leste, em área com grande atividade hidrotermal (Martins et al. 2006). De acordo com estes autores, os sulfetos polimetálicos possuem altos teores de ferro, zinco e cobre, e se encontram dispostos em depósitos aproximadamente cilíndricos, com $3 \mathrm{~m}$ a $6 \mathrm{~m}$ de altura e $5 \mathrm{~m}$ de diâmetro.

\section{Síntese da matéria orgânica}

A reação de fotossíntese utiliza a água para reduzir gás carbônico com a energia da luz, produzindo matéria orgânica e oxigênio (Jørgensen 2000). A equação da reação pode ser enunciada como:

$$
\mathrm{CO}_{2}+\mathrm{H}_{2} \mathrm{O} \rightarrow \mathrm{CH}_{2} \mathrm{O}+\mathrm{O}_{2}
$$

com $\mathrm{CH}_{2} \mathrm{O}$ simbolizando a matéria orgânica na biomassa vegetal (Tardy 1987, 1997; Jørgensen 2000). Algumas bactérias utilizam como doadores de elétrons $\mathrm{H}_{2} \mathrm{~S}, \mathrm{~S}^{0} \mathrm{e} \mathrm{Fe}^{2+}$, ao invés de $\mathrm{H}_{2} \mathrm{O}$; a oxidação do ferro pela ação dessas bactérias pode ter sido importante para a produção dos grandes volumes de formações ferríferas bandadas do Arqueano, sem a presença de $\mathrm{O}_{2}$ (Jørgensen 2000).

A fotossíntese se constitui em um processo formado por várias etapas no qual o carbono do $\mathrm{CO}_{2}$ é fixado em compostos orgânicos estáveis. A fotossíntese nas plantas C3 é descrita a seguir e esquematizada na Figura 11. Na primeira etapa da fotossíntese, ocorre a carboxilase-oxigenase da ribulose-bisfosfato $(\mathrm{RuBP})$ dentro dos cloroplastos (Ehleringer \& Cerling 2001, Wang et al. 2012).

A RuBP (uma molécula com cinco átomos de carbono) se combina com o $\mathrm{CO}_{2}$ para formar duas moléculas de fosfoglicerato (PGA, uma molécula com três átomos de carbono) (Ehleringer \& Cerling 2001). Entretanto, a RuBP é uma enzima capaz de catalisar duas reações distintas, uma levando à formação de duas moléculas de PGA na presença de $\mathrm{CO}_{2}$ e outra levando à formação de uma molécula de PGA e uma molécula de fosfoglicolato (PG, uma molécula com dois átomos de carbono), em 
presença de $\mathrm{O}_{2}$ (Ehleringer \& Cerling 2001, Wang et al. 2012). A última reação, a oxigenase, resulta em menos fixação de carbono e, eventualmente leva à produção de $\mathrm{CO}_{2} \mathrm{em}$ um processo conhecido como fotorrespiração:

$$
\begin{gathered}
\mathrm{RuBP}+\mathrm{CO}_{2} \rightarrow P G A, \\
\mathrm{RuBP}+\mathrm{O}_{2} \rightarrow P G A+P G .
\end{gathered}
$$

A proporção de tempo para a qual RuBP catalisa $\mathrm{CO}_{2}$ versus $\mathrm{O}_{2}$ depende da razão $\left[\mathrm{CO}_{2}\right] /\left[\mathrm{O}_{2}\right]$. A reação também é dependente da temperatura uma vez que a atividade da oxigenase aumenta com a temperatura. Como consequência da sensibilidade da RuBP ao oxigênio, a eficiência na formação de $\mathrm{C} 3$ decresce na medida em que o $\mathrm{CO}_{2}$ atmosférico diminui (Ehleringer \& Cerling 2001).

A fotossíntese C4 (Fig. 11) representa uma modificação biogeoquímica e morfológica da fotossíntese C3 para reduzir a atividade da oxigenase da RuBP e, assim, aumentar a taxa fotossintética em ambientes com baixo $\mathrm{CO}_{2}$ (Ehleringer \& Cerling 2001).

Nas plantas $\mathrm{C} 4$, as atividades fotossintéticas ocorrem em dois tecidos anatômica e bioquimicamente distintos das suas folhas, as células da bainha vascular e as células do mesófilo (Wang et al. 2012). Nas células do mesófilo, uma enzima muito ativa, a fosfoenolpiruvato (PEP) carboxilase, fixa o $\mathrm{CO}_{2}$ em oxaloacetato (OAA) (uma molécula que possui quatro carbonos) (Ehleringer \& Cerling 2001). Como resultado da alta atividade da PEP carboxilase, o $\mathrm{CO}_{2}$ é concentrado em regiões onde a RuBisCo (ribulose-1,5-bisfosfato carboxilase oxigenase, é a enzima responsável pela fixação do dióxido de carbono na sua forma orgânica) está localizada e isso resulta em uma alta razão $\mathrm{CO}_{2} / \mathrm{O}_{2}$ e limita a fotorrespiração. O OAA é metabolizado em malato e difundido para células da bainha celular, onde é descarboxilado e libera $\mathrm{CO}_{2}$ que é refixado na via normal de C3 (Ehleringer \& Cerling 2001). $O$ piruvato resultante da liberação do $\mathrm{CO}_{2}$ retorna às células do mesófilo para ser novamente fixado pela via $\mathrm{C} 4$. Assim, uma alta razão $\mathrm{CO}_{2} / \mathrm{O}_{2}$ é mantida no local de ação da rubisco, favorecendo a carboxilação da RuBP nas células da bainha vascular.

Por meio dos processos descritos, os organismos fotossintetizantes produzem substâncias e estruturas orgânicas a partir de compostos inorgânicos. Esse produto é incorporado ao sistema sedimentar na forma de partículas liberadas pelo organismo (troncos, folhas, sementes, pólen e esporos) ou como moléculas orgânicas resultantes da decomposição do organismo. As moléculas orgânicas produzidas dessa forma também são incorporadas à cadeia alimentar pela alimentação de organismos heterótrofos, e posteriormente são liberadas para o sistema sedimentar quando da decomposição destes organismos.

\section{Saída de massa e energia}

A saída de energia e massa no sistema sedimentar ocorre de diversas formas. A energia mecânica se dissipa, uma vez que o sistema realiza trabalho ao transportar o sedimento. A energia química presente na matéria orgânica pode se acumular, dando origem aos combustíveis fósseis. A massa sedimentar sai do sistema quando há deposição e incorporação ao registro. No caso da matéria orgânica, em função de diversos fatores, como as condições ambientais, a taxa de sedimentação, a taxa de subsidência e outros, parte deste volume pode ser decomposto pela ação bacteriana antes de se acumular. Os gases presentes na água, inclusive o $\mathrm{CO}_{2}$ produzido pela decomposição da matéria orgânica e dissolução de carbonatos podem ser devolvidos à atmosfera.

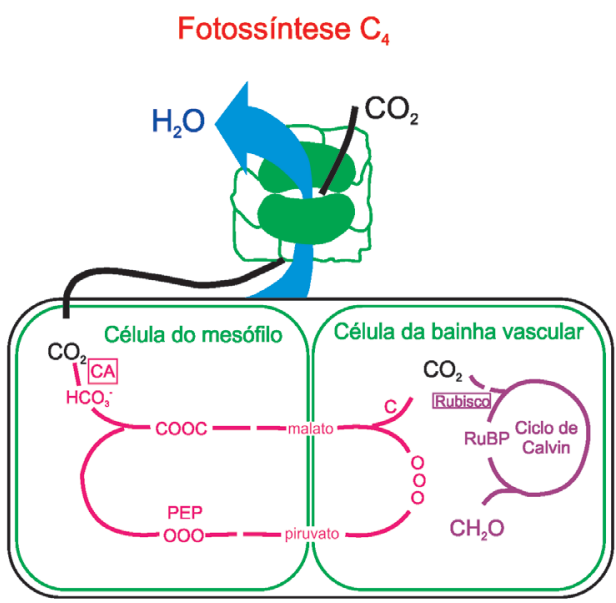

Figura 11. Desenho esquemático das reações envolvidas nos tipos $C_{3}$ e $C_{4}$ de fotossíntese em nível celular. Modificado de Wang et al. (2012). 
O sedimento acumulado também pode ser dissolvido antes de se depositar, pela ação da água presente no espaço poroso, se houver desequilíbrio químico entre a água intersticial e o sedimento. Este processo não é limitado pelo tempo nem pela profundidade na pilha sedimentar, e pode continuar ocorrendo durante a diagênese, confundindo-se, dessa forma, com os processos inerentes ao sistema litosférico.

\section{Incorporação ao registro estratigráfico}

A saída de massa sedimentar do sistema por meio da incorporação ao registro estratigráfico passa pelo problema de se definir em que momento o sedimento deixa de estar sujeito a transporte e se torna uma rocha sedimentar, incorporada a uma bacia e fazendo parte do sistema litosférico. Isto tem relação com a escala de tempo considerada, mas o tempo não é o único critério.

Alguns depósitos sedimentares podem ser acumulados e, posteriormente, remobilizados sem se tornarem rochas sedimentares. Este é o caso de barras arenosas em canais fluviais, por exemplo. As barras podem permanecer fixas por séculos, sendo inclusive cobertas por vegetação. Entretanto, alterações na descarga fluvial ou nas taxas de soerguimento da bacia causam a erosão das barras e a reentrada do sedimento no sistema.

Por outro lado, o conceito de rocha sedimentar não é necessariamente dependente do tempo. Alguns processos de litificação são muito rápidos, como os que envolvem precipitação química e bioconstruções, como no caso dos depósitos evaporíticos, calcretes, silcretes, beach rocks e recifes, não existindo uma divisão clara entre depósito e rocha sedimentar. Embora estas formações sejam mais resistentes à erosão, o fato de serem superficiais faz com que as mesmas não possam ser consideradas como fazendo parte do registro, pois no caso de uma queda no perfil de equilíbrio, mesmo que suave, elas serão inexoravelmente erodidas.

De um modo geral, pode-se afirmar que a saída da massa sedimentar pela incorporação ao registro implica na sua incorporação a outro sistema contíguo, o sistema litosférico. Assim, é fundamental que ocorra a subsidência para que um depósito sedimentar e as acumulações de matéria orgânica entrem no sistema litosférico. Quando isto ocorre, a compactação e a precipitação de cimentos atuam transformando um depósito em estrato. A partir daí, as rochas sedimentares poderão ser novamente soerguidas e erodidas.

\section{Decomposição da matéria orgânica}

Os restos de organismos macroscópicos mortos se depositam in situ ou ex situ em todos os ambientes de sedimentação do planeta. Os microorganismos mortos em geral se depositam como agregados de matéria orgânica no fundo dos oceanos e corpos d'água. Os detritos orgânicos são inicialmente alvo de organismos detritívoros e de degradação por ação bacteriana. Por serem moléculas grandes (carboidratos, proteínas, ácidos nucleicos e lipídios), os detritos orgânicos não podem ser assimilados pelas bactérias sem antes passar por um processo de despolimerização, no qual atuam exo-enzimas (Jørgensen 2000).

A matéria orgânica biodegradada pode ser adsorvida na superfície de minerais, formando "geomacromoléculas" e ser soterrada juntamente com uma fração da matéria orgânica original (Jørgensen 2000), produzindo as rochas-fontes de hidrocarbonetos.

Outro destino da matéria orgânica depositada no fundo dos ambientes de sedimentação, neste caso na zona óxica, é ser assimilada pelo metabolismo de organismos detritívoros, sendo devolvida à hidrosfera ou à atmosfera como gás carbônico por meio da respiração. $\mathrm{Na}$ zona anóxica, por sua vez, procariontes denitrificantes, redutores de óxidos metálicos e de sulfatos, também liberam gás carbônico como produto final de seu metabolismo (Jørgensen 2000). Há ainda os procariontes metanogênicos, que atuam mais efetivamente a determinada profundidade dentro dos depósitos marinhos, abaixo da zona sulfatada (Jørgensen 2000). O metano produzido pode se fixar como uma camada de hidratos de gás, em profundidades mais rasas da pilha sedimentar. No entanto, o hidrato de gás é metaestável, e o metano é liberado para a hidrosfera e a atmosfera quando a camada sofrer algum tipo de instabilidade, não sendo incorporado ao registro estratigráfico.

\section{Transferência de massa}

A massa sedimentar é transportada por meio do movimento dos fluidos que atuam na superfície da Terra. Um fluido é colocado em movimento pela energia da gravidade atuando sobre gradientes topográficos das ondas e das marés e, por correntes geradas por diferenças de densidade entre massas de ar ou água. 


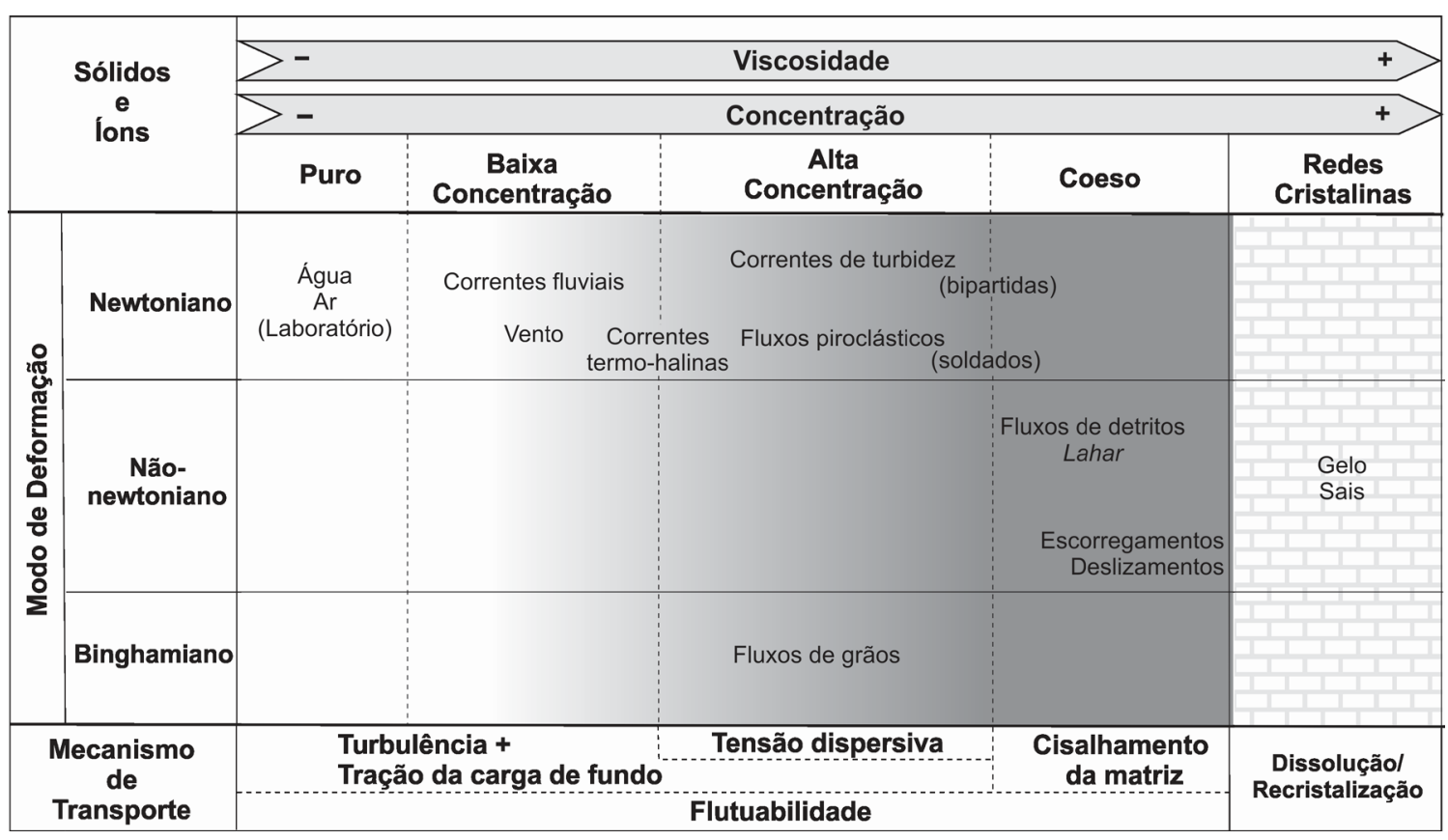

Figura 12. Diagrama posicionando os fluxos naturais possíveis na superfície da Terra, em função da reologia do fluido, concentração da mistura fluido-sedimento e mecanismos de transporte.

$\mathrm{Na}$ natureza, os fluidos podem assumir um espectro amplo de características físicas em função de sua densidade, concentração de sedimento, tamanho de grão dissolvido, características reológicas dos sedimentos, etc. Em sedimentologia este é um tema recorrente, e diferentes classificações dos fluidos foram propostas (e.g. Middleton \& Hampton 1974, Lowe 1982, Dasgupta 2003). A Figura 12 propõe uma organização possível para os fluxos encontrados na superfície da Terra e que fazem parte do sistema sedimentar. As exceções são água e ar livres de partículas, que só podem existir em condições artificiais. Os fluxos piroclásticos e a movimentação do sal são também contextualizados, mas por estarem na interface com o sistema litosférico, não serão discutidos aqui.

Fisicamente é possível haver transformações de fluxos, mas nem todos os tipos de fluidos são passíveis de evoluir para outros tipos. Por exemplo, um fluxo fluido aquoso pode incorporar uma alta concentração de sedimento e assumir características de correntes de turbidez. Por outro lado, a capacidade de um fluxo de detritos de incorporar água e se transformar numa corrente de turbidez é controversa. Embora fluxos de detritos subaquosos sejam relativamente comuns em áreas de maior inclinação, sua alta densidade e a presença de argila os torna fluxos laminares, desprovidos da turbulência que é o principal mecanismo de incorporação de água a um fluxo subaquoso de sedimentos.
Alguns materiais sólidos também se comportam como fluidos, na forma de fluxo cristalino. Nas condições superficiais, isto ocorre principalmente com o gelo e os sais. Há ainda o processo de queda livre, que ocorre quando cessa tanto o fluxo horizontal laminar quanto a turbulência. Este processo ocorre em condições subaéreas e subaquosas.

\section{Fluxos fluidos}

Os fluidos são substâncias que possuem a propriedade de apresentar deslocamentos internos e se deformam continuamente quando tensões de cisalhamento (força tangencial aplicada sobre uma área) atuam sobre elas. Isto se deve à ausência de um arranjo regular e permanente das moléculas, as quais têm liberdade para se movimentarem umas em relação às outras. Os gases apresentam essa mesma propriedade, mas o afastamento entre as moléculas é maior, tornando muito fracas as interações entre elas. Os fluxos fluidos naturais são os fluxos aquosos e o vento.

Isaac Newton forneceu as bases da mecânica dos fluidos, cujos conceitos fundamentais foram enunciados em um postulado da sua obra Princípios Matemáticos de Filosofia Natural: "A resistência que surge da falta de lubrificação nas partes de um fluido (...) é proporcional à velocidade em que as partes do fluido se separam entre si" (Newton 1686).

O comportamento newtoniano prevê que a taxa 
de deformação será sempre proporcional à tensão cisalhante aplicada, e inversamente proporcional à viscosidade. Na natureza, a tensão cisalhante é causada por gradientes - de temperatura, no caso do ar, e de altura ou temperatura, no caso da água.

Os fluidos ideais são incompressíveis e não-friccionais (Allen 1968); assim, a velocidade desses fluidos sofre variação das bordas para o centro. No entanto, fazendo-se uso de experimentos verificou-se que os fluidos reais não se comportam dessa forma, apresentando cisalhamento interno ou em relação às suas bordas (Allen 1968).

A propriedade dos fluidos reais de produzirem cisalhamento resulta no desenvolvimento de uma camada periférica junto ao fundo e às margens do duto ou canal na qual há o gradiente de velocidade, tende a zero no limite do fluxo. Isto ocorre porque na superfície de contato entre o fluido e o substrato há a atração entre as moléculas dos dois materiais, na chamada camada de adsorção. Nas outras porções do fluxo não há gradiente de velocidade, sendo a região onde se observa este gradiente denominada corrente externa ou livre (Fig. 13) (Allen 1968, 1970). A tensão cisalhante desempenha um importante papel na erosão e no desenvolvimento das formas de leito.

Para o entendimento dos processos de transporte, é importante a compreensão do conceito de turbulência, uma vez que na natureza os fluxos fluidos apresentam essa característica na maioria das vezes. Um fluido se transforma de laminar em turbulento quando o valor crítico entre as forças inerciais e viscosas é atingido, definido pelo

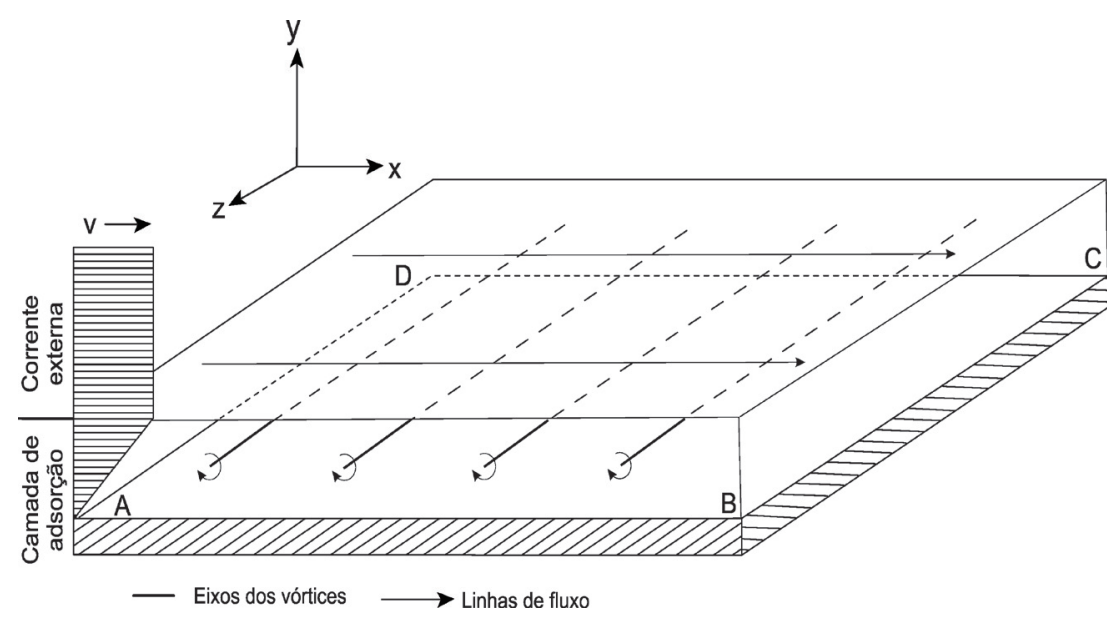

Figura 13. Anatomia de um fluxo fluido. O fluxo se desloca sobre o substrato, representado pelo plano ABCD. De acordo com o modelo newtoniano, a velocidade $v$ da camada livre decresce, tendendo a zero junto ao substrato, devido ao atrito. Isto gera cisalhamento interno e, consequentemente, a formação de células da turbulência (vórtices). Modificado de Allen (1970). número de Reynolds. Este é um valor adimensional, descrito como:

$$
R=\rho u l / \mu=u l / v,
$$

onde $\rho$ é a densidade do fluido, $u$ é a velocidade do fluxo, $l$ é uma distância característica (o lado de um cubo que representa o volume de fluido) e $v$, a viscosidade cinemática dada por $\mu / \delta$, sendo $\mu$ o coeficiente de viscosidade (Allen 1968).

De acordo com Allen (1968), o processo de transporte dos grãos corrente abaixo varia conforme o número de Reynolds. O cisalhamento viscoso domina o fluxo quando o número de Reynolds é baixo, de modo que a viscosidade do fluido intergranular determina as colisões entre os grãos, que irão se "empurrar". Por outro lado quando o número de Reynolds é alto, o cisalhamento inercial é o mecanismo preponderante, e os grãos irão ricochetear, transferindo o momento do fluido para a camada de sedimento. $\mathrm{O}$ mecanismo descrito acima se aplica para arranjos de grãos muito fechados e tamanho de grãos variando de areia (diâmetro $>64$ $\mu \mathrm{m}<2 \mathrm{~mm}$ ) a seixo (diâmetro $>4 \mathrm{~mm}-<64 \mathrm{~mm}$ ). Esse tipo de transporte é chamado de carga de fundo, ou tração (Fig. 14).

O mecanismo de transporte para partículas de areia com diâmetro menor do que $0.15 \mathrm{~mm}$ (silte e argila), é a suspensão, no qual as partículas adquirem movimento no restante da camada de fluido. Estas camadas são sustentadas pelos torvelinhos nos fluxos turbulentos. Enquanto o regime de fluxo se mantiver constante, a massa de grãos em suspensão manter-se-á igualmente constante, embora os grãos individuais retornem periodicamente à carga de fundo, a qual repõe novos grãos à suspensão.

\section{Fluxos de massa}

Os fluxos de massa são mecanicamente mais complexos do que os fluxos fluidos, uma vez que são muito efetivos em incorporar massa sedimentar do substrato, assim como em perder massa devido à deposição de uma ou mais frações granulométricas. Isto modifica os mecanismos de transporte e depo- 


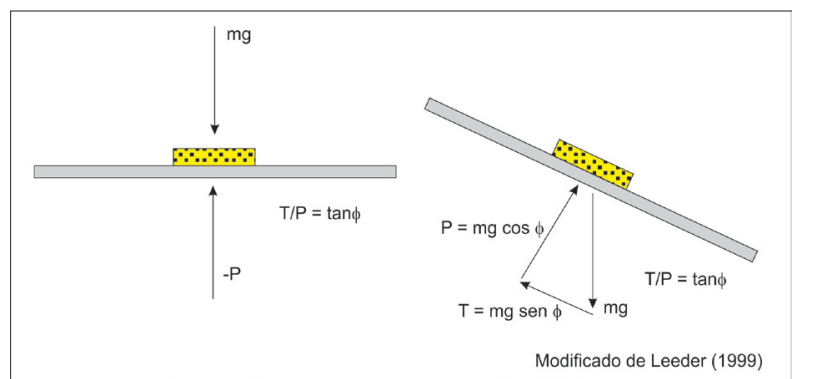

Figura 15. Parâmetros geométricos para o início de um movimento de massa. Vide texto para explanação. Modificado de Leeder (1999).

sição das partículas, o que altera o comportamento reológico do fluxo (Manica 2011). Este tipo de fluxo pode ser newtoniano, não-newtoniano ou granular (binghamiano).

Os fluxos não-newtonianos são aqueles que possuem uma relação não linear entre a tensão aplicada e a taxa de deformação, ou seja, sua viscosidade varia conforme a tensão aplicada. Este efeito é dado pelo arranjo microestrutural de suas partículas, sendo, portanto, uma característica de muitos fluidos particulados. Os fluxos granulares são aqueles em que os grãos têm certa liberdade de se moverem independentemente. Em termos mecânicos, seu modo de deformação é binghamiano, ou seja, o comportamento é igual ao newtoniano, porém é necessário que haja uma tensão cisalhante crítica para iniciar o deslocamento, a qual é definida pelo arranjo geométrico dos grãos.

Para que uma massa comece a se movimentar, é necessária uma inclinação mínima do substrato, que é dada pelo ângulo $\theta$. Considerando que a força normal $\mathrm{P}$ (peso) é dada por $P=m g \cos \theta$ e a tensão cisalhante $\tau=m g \operatorname{sen} \theta$, para que massa comece a deslizar a tensão cisalhante deve obedecer à condição $\tau \neq 0$, que por sua vez depende de que $0<\theta<90^{\circ}$ (Leeder 1999) (Fig. 15).

\section{Fluxos coesos}

Agrupa-se aqui todos os tipos de fluxos em que a massa - grãos e fluido - se movimentam sem qualquer liberdade, ou seja, grãos e fluido se movimentam juntos, sem que haja deslocamento entre eles. Seu comportamento mecânico é muito variado, em função do tipo de material constituinte, em especial a quantidade de argila, e a proporção de fluido contido, no caso a água.

Experimentos realizados por Manica (2011) mostraram que o volume de material coesivo - representado na natureza pelas argilas - é fundamental para que o fluxo assuma um compor- tamento viscoso, com baixa turbulência e dominância da reologia não-newtoniana. As observações do autor também são muito importantes no sentido de demonstrar que há uma transição entre fluxos coesos e não-coesos - correntes de turbidez stricto sensu - produzindo fluxos bipartidos, nos quais o transporte das partículas é dominado pelo cisalhamento da matriz na base e pela turbulência na parte superior mais diluída.

Os fluxos coesos mais comuns e volumetricamente mais importantes são os fluxos de detritos. Trata-se de fluxos onde os clastos de diferentes tamanhos de grão se movimentam por meio do cisalhamento da matriz argilosa com água, combinado com a flutuabilidade; os clastos não têm liberdade, resultando em pouca ou nenhuma organização interna.

A massa de sedimento permanecerá em movimento pela ação da gravidade até que a tensão gravitacional seja suplantada pela resistência do fluido, que então "congela" (Dasgupta 2003), produzindo depósitos clásticos suportados pela matriz. (Fig. 16).

Casos especiais e extremos em termos de coesão são aqueles em que uma massa de sedimento já depositada sofre uma nova movimentação. Quando não há deformação interna esse processo é chamado de deslizamento e, quando a massa sofre alguma deformação interna, é denominado escorregamento.

\section{Correntes de turbidez}

Este termo é consagrado na literatura geológica, no entanto, é necessário fazer uma ressalva. O termo "turbidez" se refere à quantidade de

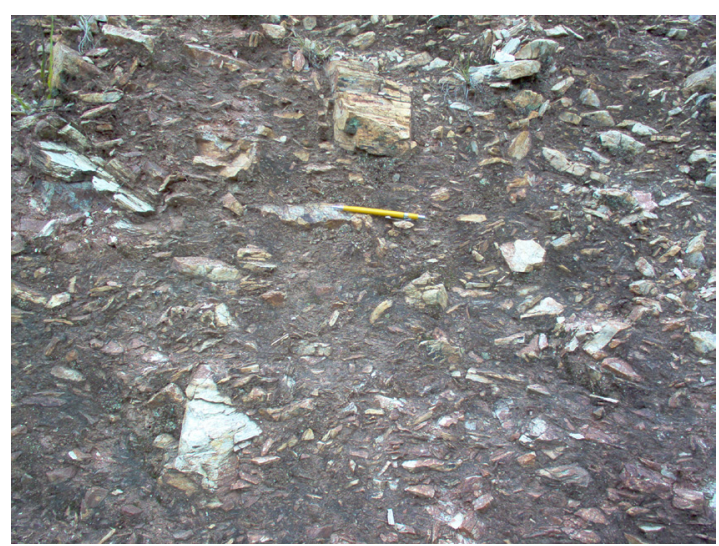

Figura 16. Depósito produzido por um fluxo de detritos, exibindo seixos de diversos tamanhos, imersos em uma matriz de granulometria mais fina. Depósitos continentais neogênicos na região das Serras de Sudeste, Santana da Boavista (RS) 


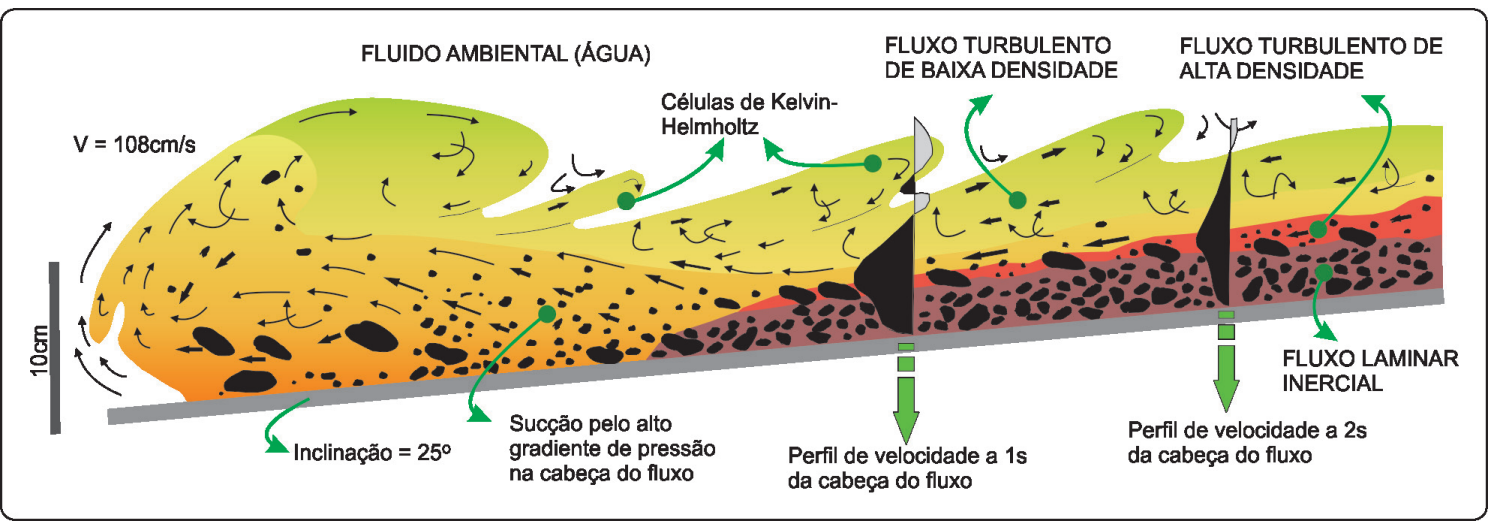

Figura 17. Anatomia de uma corrente de turbidez. Na base, observa-se uma camada de fluxo laminar, com alta densidade. A camada de topo, turbulenta, pode apresentar também um nível basal de alta densidade, logo acima da camada laminar. A camada de baixa densidade se sustenta por meio de torvelinhos. As setas indicam as linhas de fluxo. O parâmetro V é a velocidade do fluxo. Modificado de Postma et al. (1988).

partículas sólidas que há no fluido, sendo medido pela eficiência do fluido em transmitir a luz, mas a turbidez por si só não produz um fluxo. O fator fundamental que produz o deslocamento do fluido pela ação da gravidade é a sua densidade, maior do que o fluido ambiental. Embora a maioria dos fluxos subaquosos naturais seja densa, pela presença das partículas sólidas, o mesmo processo pode ocorrer devido a outros fatores tais como salinidade e temperatura.

Outro problema está em se separar as correntes de turbidez dos fluxos coesos, quando os últimos ocorrem em ambiente subaquoso. Fisicamente, os fluxos coesos são não-newtonianos, enquanto as correntes de turbidez são fluxos newtonianos, ao menos em sua parte superior. Manica (2011) demonstrou, com uso de experimentos, que as correntes de turbidez podem ter uma camada basal que se comporta como um fluxo coeso, a depender da concentração de argila.

Ao discutir problemas conceituais desse tipo, Kneller \& Buckee (2000) sugeriram definir correntes de turbidez como uma mistura de fluido e sedimento mais densa que o fluido ambiental (aquoso) e que é posta em movimento pela ação da gravidade; dessa forma, o processo é homólogo ao dos fluxos piroclásticos, embora o fluido ambiental destes seja o ar.

A Figura 17 representa uma corrente de turbidez bipartida, onde a camada basal, mais densa, apresenta movimento laminar, cujo mecanismo é o cisalhamento da matriz e a camada de topo menos densa - corrente de turbidez stricto sensu - cuja massa sedimentar é sustentada pela turbulência.

As correntes de turbidez possuem alta capacidade de segregar os grãos, formando depósitos com sucessões verticais (e.g. Bouma 1962) e horizontais (e.g. Mutti et al. 2003) muito particulares, que compreendem desde conglomerados sustentados pelos seixos até lutitos.

\section{Fluxo de grãos}

Quando os grãos ou agregados têm liberdade de se movimentar e colidir, chama-se a este processo fluxo de grãos. Mecanicamente, seu movimento é granular, onde a pressão dispersiva exerce uma importante influência.

Os fluxos de grãos são casos especiais entre os fluxos de massa. Esse tipo de fluxo é mais efetivo quando o fluido intersticial é o ar, devido à sua baixa viscosidade. Em termos de tamanho de grãos, o processo pode ocorrer em sedimentos desde a fração areia até bloco, gerando depósitos com espessuras de milímetros até dezenas de metros.

A tensão tangencial grão-grão $(T)$ gera uma tensão normal dispersiva $(P)$ entre os grãos, de acordo com a relação:

$$
T / P=\tan \varphi,
$$

onde $\varphi$ é o ângulo de fricção sólida entre as partículas (Leeder 1999). Quanto maior a superfície de atrito dos grãos, maior será a tensão dispersiva. Assim, os grãos com maior diâmetro adquirem maior energia e se deslocam em direção ao topo do fluxo, produzindo a gradação inversa. A Figura 18 mostra o processo de atuação da tensão dispersiva e a deposição de lâminas de gradação inversa, segundo Lowe (1982). Este autor menciona a ocorrência de camadas produzidas por este processo na base de algumas correntes de turbidez, denominadas de tapetes de tração. 


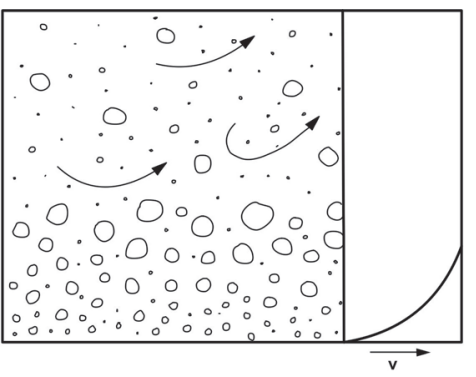

A

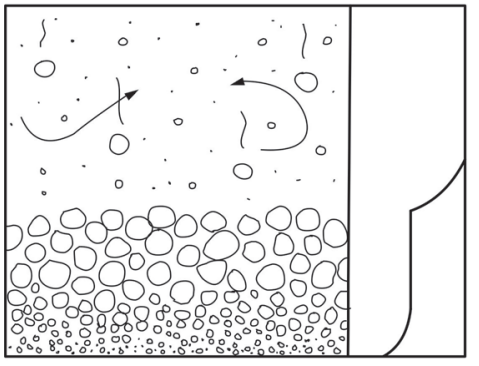

Figura 18. Evolução de um fluxo de grãos associado a fluido ambiental aquoso. (A) Um fluxo fluido turbulento com velocidade horizontal $v$ apresenta um comportamento inicial newtoniano, com velocidade menor junto ao substrato; como o fluido é rico em grãos, há uma acumulação deles em uma camada basal. (B) Como os grãos possuem liberdade, eles colidem, e a tensão tangencial gera uma tensão dispersiva que faz os grãos maiores se acumularem no topo da camada. (C) A camada basal para de se movimentar, produzindo um "tapete de tração". (D) 0 tapete de tração está sedimentado, constituindo a camada S2. Acima da camada, o fluxo segue em movimento, com comportamento newtoniano. Modificado de Lowe (1982).

\section{Fluidos cristalinos}

Alguns sólidos também podem se comportar como fluidos, segundo o processo de fluidez cristalina. Uma substância sólida pode se movimentar ao longo de uma contínua série de dissoluções e recristalizações. Os materiais geológicos que apresentam esta característica em situações superficiais são principalmente o gelo e os sais, desde que haja um gradiente. Para o sistema sedimentar, o fluxo cristalino mais importante é o do gelo.

O gelo flui quando se acumula na forma de geleiras sobre áreas altas, como montanhas e escudos continentais, onde o gradiente topográfico induz ao fluxo cristalino.

O gelo apresenta comportamento visco-elástico, ou seja, responde elasticamente à tensão aplica$\mathrm{da}$, dada pela gravidade atuando sobre um talude, até um valor crítico quando inicia a sua fluidez. $\mathrm{O}$ comportamento do gelo é do tipo não-newtoniano, conforme a relação

$$
d u / d y=k \tau^{n},
$$

onde $d u / d y$ é a taxa de deformação, $k$ uma constante definida por meio de experimentos e proporcional à temperatura, $\tau$ a tensão cisalhante e $n$ é um expoente; este último varia de 1,5 a 4,2 , enquanto que, para fluidos newtonianos, o expoente equivale à unidade (Leeder 1999). Os valores não-unitários de $n$ descrevem o comportamento não-linear da relação entre taxa de deformação e tensão para o gelo.

As grandes tensões envolvidas no fluxo de uma geleira resultam num alto poder erosivo, como atestado pela peculiar fisiografia deixada pelo gelo, com feições como fiordes, lagos e vales largos com perfil em "U". Da mesma forma, o gelo é capaz de transportar clastos de tamanhos variados, podendo chegar até seixos, matacões e blocos (Fig. 19).

\section{Queda livre}

Quando cessa a velocidade horizontal e a turbulência de um fluxo laminar capazes de manter o grão em movimento, o mesmo sofre queda livre. Esse processo pode ocorrer tanto em condições subaéreas como subaquosas. Em larga escala, nos ambientes subaéreos pode ocorrer a queda de partículas transportadas pelo vento, em zonas onde cessa ou diminui o fluxo eólico. A formação de agregados de partículas devido à diferença de carga eletrostática ou à umidade contribui no sentido de aumentar a massa do sedimento, o que facilita a deposição por queda livre (Pye 1995). Em ambientes subaquosos, as partículas decantam em corpos d'água ou nos oceanos, nas zonas sem a influência de fluxos de qualquer espécie.

\section{Formas de energia dominante e subsistemas}

Segundo a premissa de Bertallanffy (1968), um sistema mais complexo pode ser organizado em subsistemas. Isto pode ser constatado no sistema sedimentar. A energia motora das transformações verificadas nesse sistema tem diferentes origens, $\mathrm{o}$ que imprime características distintas para as diferentes regiões em que a sedimentação atua. Isto é 
particularmente relevante para a compreensão do sistema sedimentar.

A energia que impulsiona as interações entre as partículas, os fluidos e os íons pode ser de quatro formas diferentes quanto à sua origem: (i) inercial, produzida pela gravidade terrestre atuando sobre o gradiente topográfico, (ii) gravidade terrestre atuando sobre gradientes de densidade, (iii) ondas e (iv) marés. Em última análise, a energia provém da força gravitacional (da própria Terra, da Lua e do Sol), do calor do Sol e, de forma localizada, do calor do interior da Terra. Mas a forma final com que a energia atua sobre o sedimento e os fluidos é distinta em cada caso. Propõe-se aqui que cada um desses casos represente um subsistema.

A Figura 2 mostra de forma simplificada a distribuição das formas de energia e dos subsistemas assim estabelecidos. A energia inercial é responsável pelo fluxo de água, de massa sedimentar e do gelo. Sua atuação se dá em canais (fluviais, glaciais, submarinos) e em zonas de espraiamento (leques aluviais, deltas, geleiras de piemonte, lobos submarinos). Os contrastes de densidade produzem os ventos, que dominam os processos sedimentares em algumas regiões, como campos de dunas eólicas, planícies de deflação eólica e planícies de loess. Em ambiente subaéreo, os gradientes de densidade são responsáveis pela circulação nos corpos d'água e nos oceanos, o que é importante para o transporte, em especial de partículas de menor massa. As ondas são produzidas pelo atrito do vento com a superfície da água e são particularmente importantes para a transferência de massa nos oceanos e corpos d'água de grandes dimensões. As controlam o transporte

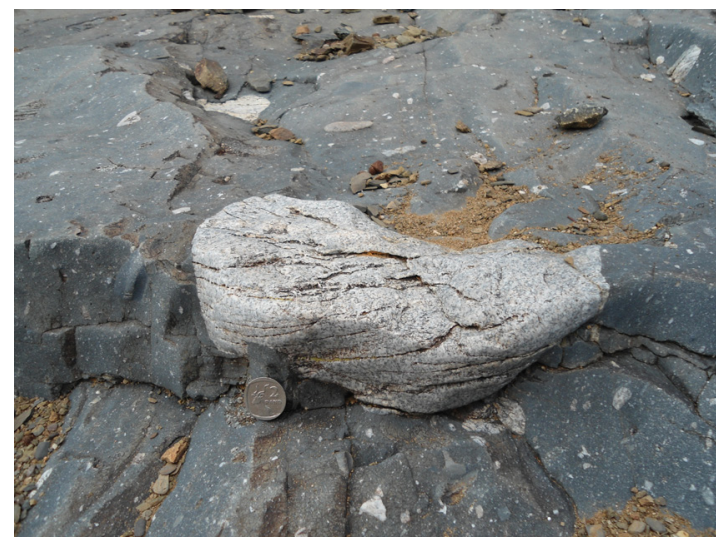

Figura 19. Diamictito produzido pelo transporte glacial durante a glaciação gonduânica (PermoCarbonífero), exibindo clastos de diferentes tamanhos de grão, com destaque para um seixo facetado pela abrasão (Grupo Dwyka, Bacia do Karoo, Laingsburg, África do Sul). e a deposição de sedimento nas regiões costeiras, onde a massa d'água movimentada pelas ondas é capaz de tocar o fundo. A atração gravitacional da Lua e do Sol atua sobre as massas d'água, na forma de uma onda com frequência de 12 horas e amplitudes variadas. Da mesma forma que as ondas produzidas pelo vento, é nas regiões costeiras que a sua atuação é mais efetiva para o sistema sedimentar.

Cada subsistema encerra características particulares, na forma de processos sedimentares distintos. O geólogo estuda o produto final desses processos, incorporado ao registro estratigráfico, na forma de fácies sedimentares e tratos de fácies. Uma análise mais detalhada dos subsistemas, no entanto, está além do escopo deste trabalho.

\section{Considerações Finais}

Neste artigo procurou-se abordar os processos envolvidos na sedimentação de uma forma sistêmica, no que foi denominado de sistema sedimentar. Este sistema se desenvolve na interface entre a litosfera, a hidrosfera e a atmosfera e possui os atributos de um sistema, na acepção definida pela Teoria Geral dos Sistemas (cf. Bertalanffy 1968). O sistema apresenta entrada e saída de massa e de energia, uma finalidade, a qual pode ser considerada como a busca constante da estabilidade no balanço entre erosão e deposição, e ainda pode ser dividido em subsistemas.

Abordar a sedimentação como um sistema organizado pode ser uma alternativa didática. Isto leva a uma visão menos fragmentada dos processos em questão, que permite aos alunos de geociências contextualizar todos os elementos. Sedimentos siliciclásticos, químicos, bioclásticos, matéria orgânica, bem como os diferentes tipos de fluidos presentes na natureza, podem ser assim ser integrados, o que evitaria a separação existente entre disciplinas como Sedimentologia, Paleontologia e Geoquímica. Além disso, esta abordagem permite encontrar similaridades entre processos que ocorrem em regiões muito distantes do ponto de vista geográfico e que, por isso, costumam ser apresentadas separadamente no ensino tradicional de Sedimentologia.

\section{Agradecimentos}

Os autores agradecem aos colegas Seirin Shimabukuro e Tiago Agne de Oliveira pelas valiosas recomendações de bibliografia. Aos dois revisores anônimos, pelas importantes sugestões e correções. 


\section{Referências}

Allen J.R.L. 1966. On bed forms and palaeocurrents. Sedimentology, 6: 153-190.

Allen J.R.L. 1968. Current ripples. Their relation to patterns of water and sediment motion. Amsterdam: North Holland Publishing Company. 433 p.

Allen J.R.L. 1970. Physical processes of sedimentation. London: Unwin University Books, Earth Sciences Series, 1. 248 p.

Berendsen H.J.A., Stouthamer E. 2000. Late Weichselian and Holocene palaeogeography of the RhineMeuse delta, The Netherlands. Palaeogeogr., Palaeoclimatol., Palaeoecol., 161: 311-335.

Bertalanffy L.von 1968. Teoria Geral dos Sistemas. Trad. Francisco M. Guimarães. Petrópolis: Editora Vozes, 5a edição, 2010. 360p.

Bonatti E., Nayudu R. 1965. The origin of manganese nodules on the ocean floor. Am. J. Sci., 263:17-39.

Bouma A. H. 1962. Sedimentology of some flysch deposits: a graphic approach to facies interpretation. Amsterdam: Elsevier. 168 p.

Branco S. M. 1989. Ecossistêmica. Uma abordagem integrada dos problemas do meio ambiente. São Paulo: Editora Edgard Blücher. 141p.

Bridge J. S., Leeder M.R. 1979. A simulation model of alluvial stratigraphy. Sedimentology, 26: 617-644.

Bridge J. S., Demicco R. V. 2008. Earth surface processes, landforms and sediment deposits. Cambridge: Cambridge University Press. 815 p.

Cappellen P. van, Dixit S., Beusekom J. van 2002. Biogenic silica in the oceans: Reconciling experimental and field-based dissolution rates. Global Biogeochemical Cycles, 16(4): 1-10.

Condie K. C. 1997. Plate tectonics and basin evolution. Oxford: Butterworth-Heinemann, $4^{\text {a }}$ edição. 282p.

Dasgupta P. 2003. Sediment gravity flow. the conceptual problems. Earth-Sc. Rev., 62: 265-281.

Davis W. M. 1902. Baselevel, grade and peneplain.J. Geol., 10(1): 77-111.

DeMaster D. J. 1981. The supply and accumulation of sílica in the marine environment. Geoch. Cosmoch. Acta, 45: 1715-1732.

Ehleringer J. R., Cerling, T. E. 2001. Photosyntetic pathways and climate. In: Schulze E.-D., Heimann M., Harrison S., Holland E., Lloyd J., Prentice I. C., Schimel D. eds 2001. Global Biogeochemical Cycles in the Climate System. Academic Press. p. 267-276.

Erez J. 2003. The source of ions for biomineralization in foraminifera and their implications for paleoceanographic proxies. Rev. Mineral. Geochem., 54 (1): 115-149.

Formoso M. L. L. 2006. Some topics on geochemistry of weathering: a review. An. Acad. Bras. Ciên., 78(4): 809-820.
Gilbert G. K. 1877. Geology of the Henry Mountains. Washington D.C.: Department of Interior, U.S. Geographical and Geological Survey of the Rocky Mountain Region. 160 p.

Gislason S. R., Oelkers E. H. 2011. Silicate rock weathering and the global carbon cycle. In: Harmon R. S., Parker A. eds. 2011. Frontiers in Geochemistry: Contribution of Geochemistry to the Study of the Earth. West Sussex: Wiley-Blackwell. p. 84-103.

Hansen H. J. 2002. Shell construction in modern calcareous foraminifera. In: Sen Gupta B. K. ed. 2002. Modern foraminifera. Dordrecht: Kluwer Academic Publishers, $2^{\mathrm{a}}$ impressão. p. 57-70.

Huggett R. 2007. A history of the systems approach in geomorphology. Géomorphologie: relief, processus, environnement, 2: 145-158.

Humbert L. 1972. Recherche métodologique pour la restitution de $\mathrm{l}^{\prime}$ histoire bio-sédimentaire d'un bassin. Revue de L'Institut Français du Pétrole, 27(1): 3-367.

James N. P., Dalrymple R. W. 2010. Facies Models 4. GEOText 6, Geological Association of Canada. 586p.

Jørgensen B. B. 2000. Bacteria and marine biogeochemistry. In: Schulz H. D., Zabel M. eds. 2000. Marine geochemistry. Berlin: Springer Verlag. p. 173-207.

Kendall A. C. 1992. Evaporites. In: Walker R. G., James, N. P. eds. 1992. Facies models. Response to sea level changes. St. John's: Geological Association of Canada. p. 375-409.

Kneller B., Buckee C. 2000. The structure and fluid mechanics of turbidity currents: a review of some recent studies and their geological implications. Sedimentology, 47: 62-94.

Kneller B. 2003. The influence of flow parameters on turbidite slope channel architecture. Mar. Petrol. Geol., 20: 901-910.

Langbein W. B., Schumm, S. A. 1958. Yield of sediment in relation to mean annual precipitation. Trans. Am. Geoph. Union, 39(6): 1076-1084.

Leeder M. 1999. Sedimentology and Sedimentary Basins. From Turbulence to Tectonics. Oxford: Blackwell Science. 592 p.

Lowe D. R. 1979. Sediment gravity flows: their classification and some problems of application to natural flows and deposits. SEPM Special Publication, 27: 75-82.

Lowe D. R. 1982. Sediment-gravity flows: II. Depositional models with special reference to the deposits of high-density turbidity currents. J. Sedim. Petrol., 52(1): 279-297.

Lyle M. 1982. Estimating growth rates of ferromanganese nodules from chemical compositions: implications for nodule formation processes. Geoch. Cosmoch Acta, 46: 2301-2306. 
Mackin J. H. 1948. Concept of the graded river. Bull. Geol. Soc. Am., 59: 463-512.

Manica R. 2011. Sediment Gravity Flows: Study Based on Experimental Simulations. In: Schulz H. E., Simões A. L. A., Lobosco R. J. eds 2012. Hydrodynamics - Natural Water Bodies. InTech, p. 263-286.

Martins L. R., Barboza, E. G., Rosa M. L. C. C. 2006. Nódulos polimetálicos e outros depósitos de mar profundo: o retorno do interesse. Gravel, 4: 125-131.

Mello, M. F., Barros, V. M., Sommerman, A., 2002. Introdução. In: Sommerman, A., Mello, M. F., Barros, V. M. orgs 2002. Educação e Transdisciplinaridade II. São Paulo: TRIOM, p. 9-25.

Middleton G. V., Hampton M. A. 1973. Sediment gravity flows: mechanics of flow and deposition. In: Turbidites and deep water sedimentation. SEPM, Pacific Sec. Short Course Lecture Notes. p. 1-38.

Milliman J. D. 1993. Production and accumulation of calcium carbonate in the ocean: Budget of a nonsteady state. Global Biogeochemical Cycles, 7(4): 927-957.

Mohriak W., Szatmari P. 2008. Introdução às propriedades químicas e físicas dos evaporitos. In: Mohriak W., Szatmari, P. Anjos, S. M. C. eds. 2008. Sal. Geologia e Tectônica. São Paulo: Beca Edições. p. 19-40.

Mohriak W., Szatmari P., Anjos S. M. C. 2008. Sedimentação de evaporitos. In: Mohriak W., Szatmari P., Anjos S. M. C. eds. 2008. Sal. Geologia e Tectônica. São Paulo: Beca Edições. p. 65-88.

Mutti E., Tinterri R., Benevelli G., Biase D. di, Cavanna G. 2003. Deltaic, mixed and turbidite sedimentation of anciente foreland basins. Mar. Petrol. Geol., 20: 733-755.

Newton, I., 1686. Princípios matemáticos de filosofia natural. São Paulo: Nova Stella e Editora da USP. 292p.

Nelson D. M. Tréguer P., Brzezinski M. A., Leynaert A., Quéguiner B. 1995. Production and dissolution of biogenic silica in the ocean: revised global estimates, comparison with regional data and relationship to biogenic sedimentation. Global Biogeochemical Cycle, 9(3): 359-372.

Nooijer L. J. de, Toyofuku T., Kitazato H. 2009. Foraminifera promote calcification by elevating their intracellular pH. PNAS: 106(36): 15374-15378.

Palma J. J. C., Pessanha I. B. M. 2000. Depósitos ferromanganesíferos de oceano profundo. Braz. J. Geoph., 18(3): 431-446.

Postma G., Nemec W., Kleinspehn K. L. 1988. Large floating clasts in turbidites: a mechanism for their emplacement. Sedim. Geol., 58: 47-61.

Price N. J. 1966. Fault and Joint Development. Oxford: Pergamon Press. 176p.

Pye K 1995. The nature, origin and accumulation of loess. Quaternary Science Reviews, 14: 653-667.

Reading H. G. 1996. Sedimentary environments: processes, facies and stratigraphy. Blackwell Science, $3^{\text {rd }}$ edition. 688p.

Reineck H-E., Singh I. B. 1980. Depositional Sedimentary Environments. With Reference to Terrigenous Clastics. Berlin: Springer-Verlag. 549p.

Riemann F. 1983. Biological aspects of deep-sea manganese nodule formation. Oceanologica Acta, 6(3): 303-311.

Schneider R. R., Schulz H. D., Hensen C. 2000. Marine carbonates: their formation and destruction. In: Schulz H. D., Zabel M. eds. 2000. Marine geochemistry. Berlin: Springer Verlag. p. 283-307.

Schumm S. A. 1977. The fluvial system. New York: John Wiley e Sons. 338 p.

Schumm S. A. 1993. River response to base level change: Implications for sequence stratigraphy. J. Geol., 101: 279-294.

Silva, C. A. P., 2007. O Manifesto da Transdisciplinaridade. Revista Famecos, 32: 137-139.

Tardy Y. 1987. Une introduction a la géochimie globale. Geochimica Brasiliensis, 1(1):19-39.

Tardy Y. 1997. Geoquímica Global: oscilações climáticas e evolução do meio ambiente desde quatro bilhões de anos. Trad. Toledo M. C. M. Estudos Avançados, 11(30): 149-173.

Walker R. G., James, N. P. 1992. Facies models. Response to sea level changes. St. John's: Geological Association of Canada. 409p.

Walther J. 1894. Einleitung in die Geologie als Historische Wissenschaft. Jena: Gustav Fischer Verlag. 3 v., $1055 \mathrm{p}$.

Wang C., Guo L., Wang Z. 2012. Systematic comparison of $\mathrm{C} 3$ and $\mathrm{C} 4$ plants based on metabolic network analysis. BMC Systems Biology, 6(suppl): S9.

Resumo: A sedimentação pode ser vista como um sistema na superfície da Terra. A mesma apresenta um atributo fundamental de sistema, a equifinalidade, traduzida na busca da estabilidade entre erosão e deposição. 0 sistema sedimentar possui entrada e saída de massa e energia e transferência interna de massa. A energia adicionada é térmica e gravitacional. A massa é incorporada por meio de absorção de gases atmosféricos, chuva e neve, intemperismo e erosão, e fotossíntese. A energia sai como de perda de calor e acumulação de energia química nas rochas. A massa é perdida por intermédio da incorporação ao registro estratigráfico, decomposição da matéria orgânica e liberação de gases para a atmosfera. É possível ainda uma divisão em subsistemas, com base na energia motora: (i) inércia, (ii) gradientes de densidade, (iii) marés e (iv) ondas. Em termos didáticos, a visão sistêmica aproxima disciplinas como sedimentologia, paleontologia e geoquímica.

Palavras-Chave: Teoria Geral dos Sistemas, sedimentação. 